\title{
Description of Poecilia (Acanthophacelus) wingei n. sp. from the Paría Peninsula, Venezuela, including notes on Acanthophacelus Eigenmann, 1907 and other subgenera of Poecilia Bloch and Schneider, 1801 (Teleostei, Cyprinodontiformes, Poeciliidae)
}

\author{
Fred. N. Poeser ${ }^{1}$, Michael Kempkes ${ }^{2}$, Isaäc J. H. Isbrücker ${ }^{1}$ \\ ${ }^{1}$ Zoological Museum Amsterdam, University of Amsterdam, P.O. Box 94766, 1090 GT, Amsterdam, The Nether- \\ lands, e-mail: poeser@science.uva.nl; 2 Am Mühlenberg 25, D-46419 Isselburg - Anholt, Germany
}

Keywords: Guppies, Poecilia reticulata, P. wingei, melanophore patterns, character displacement, Paría Peninsula, despeciation

\begin{abstract}
The taxonomy of the common guppy, Poecilia reticulata Peters, 1859 , is reviewed and the closely related Campoma guppy, $P$. wingei $\mathrm{n}$. sp., is described. Formerly, the common guppy was not judged to be closely related to any other species of Poecilia, but the new species is the second species to be allocated in the subgenus Acanthophacelus Eigenmann, 1907. The recognition of $P$. wingei results from observed character displacement, i.e., on the interaction between two closely related species in a shared environment. In addition to differences in coloration, behaviour also indicates specific differences. The area in which $P$. wingei occurs, the Campoma region at the base of the Paría Peninsula in Venezuela, hints to an origin of the subgenus Acanthophacelus prior to the uplift of the Cordilleras, i.e., the eastern orogenesis of the Andes. Moreover, an explanation is offered for aberrant molecular data in Trinidadian guppies.
\end{abstract}

\section{Contents}

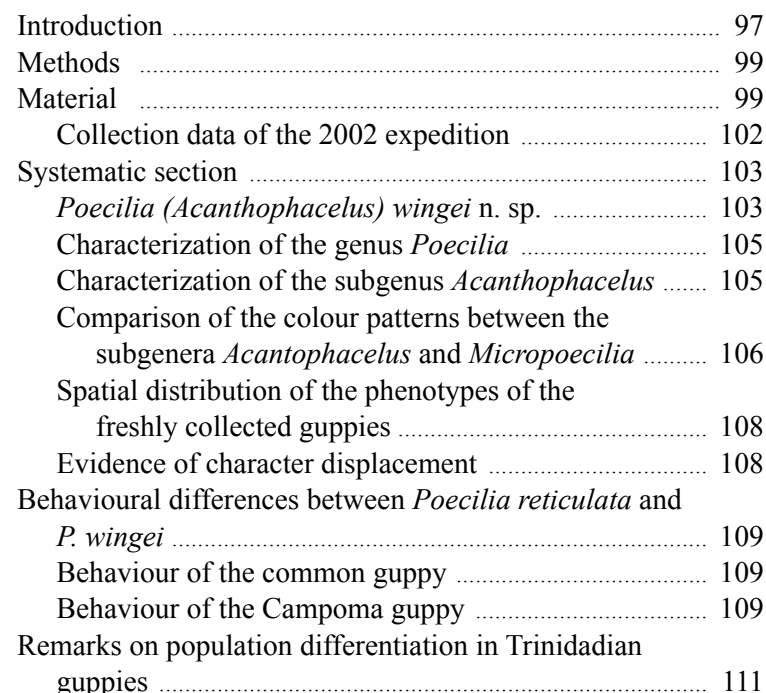

Remarks on the 'Endler's live-bearer' ...................................... 113

Acknowledgements ............................................................ 114

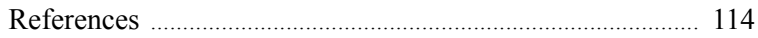

\section{Introduction}

The common guppy, Poecilia reticulata Peters, 1859, has a long history as a monotypic taxon. Poeser (2003, chapter 11) considered Poecilia Bloch and Schneider, 1801 as a monophyletic assemblage of nine morphological distinct species groups, all with their own evolutionary origin but with no species group more related to one group or the other. Because the morphological distinctions are sometimes quite remarkable, a further in-group analysis was performed (Poeser, unpubl.) and the apparent autapomorphies for $P$. reticulata (cf. Poeser, 2003, chapter 9) proved to be synapomorphies for $P$. reticulata and the species described as new herein. The subgenus Acanthophacelus Eigenmann, 1907 is again recognised based on these synapomorphies (cf. Poeser and Isbrücker, 2002; Poeser and Isbrücker, in Poeser, 2003), prompting a re-examination of all species groups mentioned in Poeser (2003, chapter 9).

Poecilia (Acanthophacelus) reticulata is a wellknown little fish, whereas its taxonomic allocation was fuzzy. Based on a single female, Peters (1859) allocated a new species from Venezuela to the genus Poecilia, viz., P. reticulata. Since Peters (1859) did not mention more specimens, the taxonomic status of this species is based on this single specimen (Poeser and Isbrücker, 2002; Poeser and Isbrücker, in Poeser, 2003, chapter 6). In addition, conspecific specimens from the same lots as the holotype (topo- 
types) were shipped by Peters from Berlin to London (Paepke, 1986). They were recorded by Günther (1866) as Girardinus reticulatus, and were compared to Girardinus guppii Günther, 1866. Girardinus Poey, 1854 (type species, G. metallicus Poey, 1854), is a valid genus, distantly related to Poecilia. The type material of Girardinus guppii was examined (Poeser, submitted manuscript) and confirmed as identical to P. reticulata.

Eigenmann (1907) examined specimens collected from Barbados and Guyana. He allocated the guppy to a distinct genus, viz., Acanthophacelus Eigenmann, 1907, mainly based on structures of the gonopodial tip. Eigenmann (1907) designated Poecilia reticulata Peters, 1859 type species for his new genus.

In a breeding report concerning guppies in the Royal Botanical Gardens in London, Boulenger (1912) mentioned guppies as the only freshwater fish on Barbados, which island was the alleged type locality of Lebistes poecilioides De Filippi, 1861, thus naming this species Girardinus poecilioides. Regan (1913) changed this by re-naming this species Lebistes reticulatus. Lebistes remained monospecific until Rosen and Bailey's (1963) revision of the Poeciliidae, in which Poecilia (Lebistes) reticulata was joined in one subgenus with four species of Micropoecilia Hubbs, 1926 (Table I), and with Cnesterodon scalpridens Garman, 1895. The latter species was re-allocated by Costa (1991) as Pamphorichthys scalpridens, whereas Poecilia (Micropoecilia) was considered as a distinct genus by Meyer (1993). Thereafter, the guppy largely remained in the monospecific subgenus Lebistes, although not without debate (cf. Costa and Sarraf, 1997; Poeser and Isbrücker, 2002; Poeser and Isbrücker, in Poeser, 2003).

The phylogenetic analysis of Rodriguez (1997) did not adequately resolve the taxonomy concerning
P. reticulata. He established his Mollienesia on the basis of the terminal hooks on the gonopodium and Poecilia by the bumps on ray 4 a. Poecilia reticulata possesses both a hook on the gonopodium and has a 'bumpy' gonopodial ray 4a, i.e., it has both of the above features. Rodriguez (1997: 673) thus was contradicting his own character assessment. Also phylogenetic analyses based on molecular data (Ptacek and Breden, 1998; Breden et al., 1999) did not render a resolved taxonomy. Moreover, the latter phylogeny clustered $P$. reticulata with $P$. parae and $P$. picta, separating these species from the remaining species of Poecilia. Based on the very distinct morphology that is presented in this paper, we hold the guppy distinct from the other species of Poecilia and we split $P$. reticulata and the new species off from the species of Micropoecilia, viz., $P$. parae Eigenmann, 1894, $P$. branneri Eigenmann, 1894, P. bifurca (Eigenmann, 1909), P. picta Regan, 1913 and P. minima Costa and Sarraf, 1997. Differences between $P$. reticulata, $P$. parae and $P$. branneri are summarised in Table II.

Another method to unravel taxonomic difficulties is to study behavioural patterns, preferably under natural conditions (Clark and Aronson, 1951; Liley, 1966). Studies on guppy behaviour yielded a standard description for mating behaviour in P. reticulata (cf. Baerends et al., 1955; Table III). Because the initial attempts to distinguish a new species of guppies based on preserved material was inconclusive, it was decided to make field observations on behavioural aspects, in order to gain insight on possible specific differentiations. Collection data of this field trip are herein presented separately from the materials examined prior to this journey.

Detailed information on guppy populations is fragmented and concerns examinations on a local scale, e.g., Trinidad. General information on morphometric and pigmentational data comprising the

Table I. Allocation of species of the subgenus Lebistes sensu Rosen and Bailey, 1963.

Poecilia reticulata Peters, 1859

Poecilia wingei $\mathrm{n}$. sp.

Poecilia parae Eigenmann, 1894

Poecilia branneri Eigenmann, 1894

Poecilia bifurca (Eigenmann, 1909)

Poecilia picta Regan, 1913

Poecilia minima Costa and Sarraf, 1997

Poecilia scalpridens Garman, 1895
Poecilia (Acanthophacelus) reticulata

Poecilia (Acanthophacelus) wingei

Poecilia (Micropoecilia) parae

Poecilia (Micropoecilia) branneri

Poecilia (Micropoecilia) bifurca

Poecilia (Micropoecilia) picta

Poecilia (Micropoecilia) minima

Pamphorichthys scalpridens (cf. Costa, 1991). 
total natural range of variation in guppies is not fully comprehended, although local studies have provided information on evolutionary mechanisms shaping guppy characteristics. While it is unknown what the complete natural range of $P$. reticulata is, what the natural variation in colour patterns is, or what the variation in their anatomy is, no standard is available to which potential new species can be compared. In order to provide a more specific description of this otherwise well studied species, this study first provides such descriptions for the two species of Venezuelan guppies.

\section{Methods}

To catalogue variation in melanophore patterns, material of the Zoological Museum in Amsterdam (ZMA) and the University of Michigan (UMMZ) was examined. Arbitrarily, ten males and ten females from UMMZ 158720, Ciudad Bolivar, Venezuela, were selected to set an initial standard. Primarily, only black spots were noted. Both sides of at least five males of the additional UMMZ samples were examined. Horizontal lines were scored on the anterior part of body (body line) and on the caudal peduncle (caudal line). Some melanophore patterns are illustrated (Figs. 1-5), and the gonopodia of these specimens (Fig. 6). Morphometric features scored were standard length (SL) and the least depth of the caudal peduncle. The average standard lengths of the populations and the proportional size of the caudal peduncle (as percents of SL) are recorded as follows: (number of individuals measured; range of measurements): average.

Extralimital material of the Zoological Museum of Amsterdam (ZMA) was examined to demonstrate variation in pigmentation. In July 2002, Poeser and Kempkes made a field trip to Venezuela. On the west side of the Paría Peninsula, they collected the species that is described as new in the present paper.

In the diagnosis, the following abbreviations are used. A. = number of anal fin rays; D. = number of dorsal fin rays; C. = number of caudal fin rays; LLS. $=$ number of scales in a lateral series; CPS. $=$ number of scales around the caudal peduncle.

\section{Material}

Standard population for Poecilia reticulata, UMMZ 158720 (44 specimens), Venezuela, Ciudad Bolivar, Río Tanguati, tributary to Río Caroni to Orinoco, 11-03-1939, coll. F. F. Bond. Average length females (10; 18.4-23.8): $20.4 \mathrm{~mm} \mathrm{SL}$, males (10; 12.915.0): $14.2 \mathrm{~mm}$ SL. Average least depth caudal peduncle females (10; 9.0-11.9): 11.0, males (10; 10.1-14.0): 11.9. Some females may have weak blotches. Males have caudal lines, four (of ten) have a body line as well. All males have a spot on the anterior part of body: six have this spot dorsally and four ventrally, one male only has a spot on the left side of his body. Five males (of ten) have a black spot halfway on the body: two dorsally and three ventrally. Two of the latter males only on the left side of the body, one male only on the right side. Six males have a spot on the caudal peduncle, just in front of, or just on the caudal fin, two males with a caudal spot only at the right side of the body. One male has the left spot just in front of the caudal fin, the right spot just on the caudal fin.

Table II. Anatomical differences between Poecilia reticulata, P. parae and P. branneri.

\begin{tabular}{|c|c|c|c|}
\hline & Poecilia reticulata & Poecilia parae & Poecilia branneri \\
\hline Polychrome body & $\begin{array}{l}\text { Males are all different, } \\
\text { no fixed patterns }\end{array}$ & $\begin{array}{l}\text { Males exhibit three or } \\
\text { four fixed colour patterns }\end{array}$ & $\begin{array}{l}\text { Males exhibit a single } \\
\text { fixed colour pattern }\end{array}$ \\
\hline Female body pigmentation & $\begin{array}{l}\text { Females without } \\
\text { humeral blotch }\end{array}$ & $\begin{array}{l}\text { Females frequently with a } \\
\text { humeral blotch }\end{array}$ & $\begin{array}{l}\text { Females with a humeral blotch } \\
\text { and a blotch at the caudal base }\end{array}$ \\
\hline Gonopodial structures & $\begin{array}{l}\text { Palp on ray } 3 \text { extending } \\
\text { clearly beyond the tip; } \\
\text { hook on ray } 5 p\end{array}$ & $\begin{array}{l}\text { Palp on ray } 3 \text { reaching tip; } \\
\text { no hooks or spine }\end{array}$ & $\begin{array}{l}\text { Palp on ray } 3 \text { reaching tip; } \\
\text { no hooks or spine }\end{array}$ \\
\hline Meristic data & $\begin{array}{l}\text { Nine anal fin rays; six or } \\
\text { seven dorsal fin rays (modally) }\end{array}$ & $\begin{array}{l}\text { Eight anal fin rays; eight } \\
\text { dorsal fin rays (modally) }\end{array}$ & $\begin{array}{l}\text { Eight anal fin rays; eight dorsal } \\
\text { fin rays (modally) }\end{array}$ \\
\hline
\end{tabular}

Table III. Standard of behavioural sequences in Poecilia reticulata (After Baerends et al., 1955)

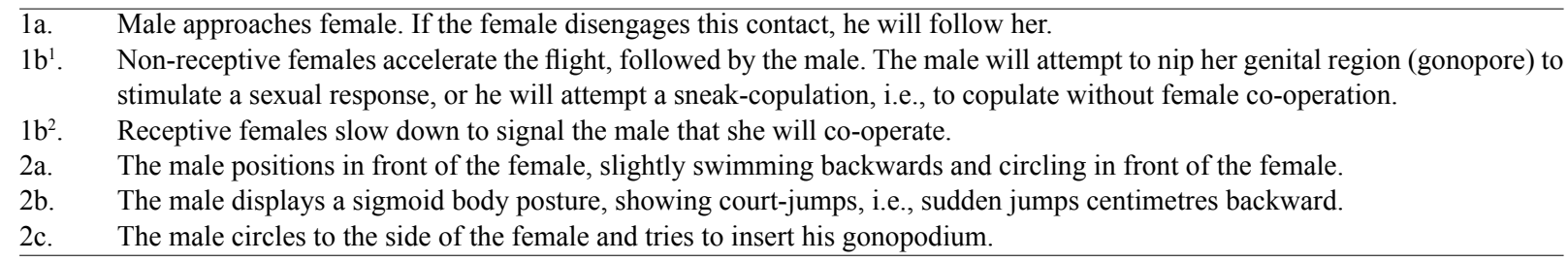


UMMZ 158704 (30 of 1074), Venezuela, $5 \mathrm{~km}$ east of San Mateo, $70 \mathrm{~km}$ south of Barcelona, Río Punctual, tributary to Río Araque, 21-03-1939, coll. F. F. Bond. Average length females (5; 23.1-25.9): $23.9 \mathrm{~mm}$ SL, males (5; 13.7-15.6): $14.9 \mathrm{~mm}$ SL. Average least depth caudal peduncle females (5; 11.3-137): 12.8, males $(5 ; 12.7-14.1)$ : 13.4 . This population is seemingly more coloured than UMMZ 158720. One female has a black spot at the caudal peduncle. All males have caudal lines, some have a body line as well. One male exhibits a double body line, as margins of a brighter band between them. Three males (of five) have a spot in the anterior section of their bodies, two other males have a spot halfway the body. All males have a caudal spot, in some it is more anterior than in others. Several males have brighter areas on their flanks, suggesting that other colour spots were present. The unpaired fins are pigmented.

UMMZ 158706 (30 of 656), Venezuela, Isla de Margarita, El Valle, Río Porlamar, 31-03-1939, coll. F. F. Bond. Average length females (5; 35.0-40.4): $37.9 \mathrm{~mm} \mathrm{SL}$, males (5; 18.5-19.0): 18.8 $\mathrm{mm}$ SL. Average least depth caudal peduncle females $(5 ; 15.2-$ 17.3): 16.2, males (5; 16.8-19.5): 18.0. Two females with a spot in the caudal fin, one up, one down. Males mostly multi-spotted, varied on left and right side of body (Figs. 1a-d). Body- and caudal lines frequently thickened into spots. Many males with caudal fin patterns.

The gonopodium of one of the males (Fig. 1c) is also figured (Fig. 6).

UMMZ 158711 (69), Venezuela, $30 \mathrm{~km}$ east of Upata, Río Charichapo, tributary to Río Yuruori, 12-03-1939, coll. F. F. Bond. Average length females (5; 18.0-21.2): $19.8 \mathrm{~mm} \mathrm{SL}$, males (5; 13.7-15.4): $14.4 \mathrm{~mm}$ SL. Average least depth caudal peduncle
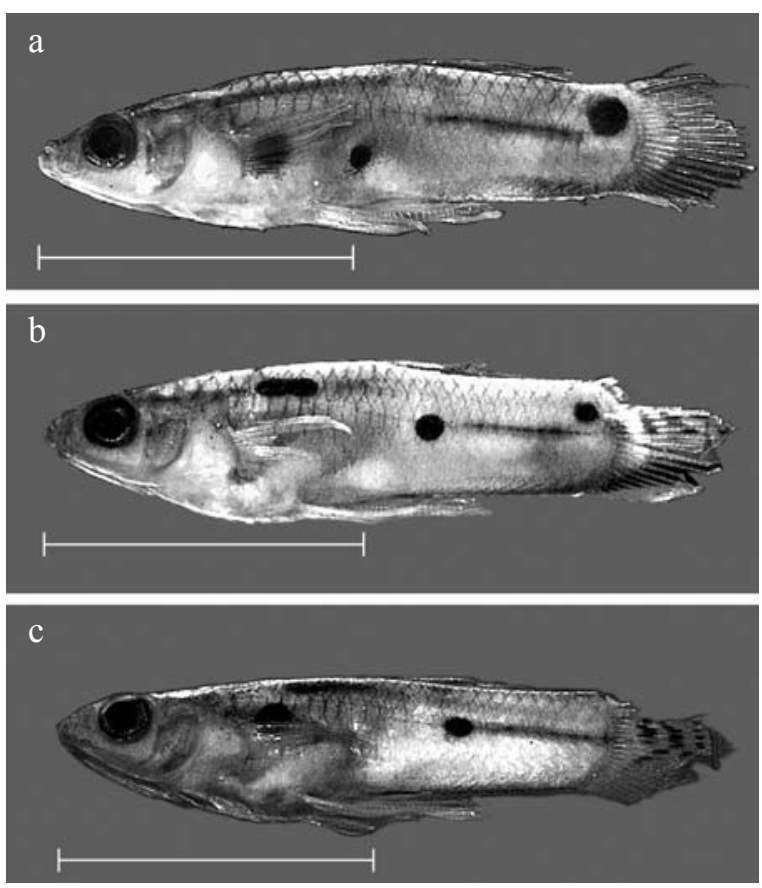

Fig. 1a-c. (Photographs by J. v. Arkel). Pigmentation patterns of male guppies from Isla de Margarita, Venezuela (UMMZ 158706). Scale is $1 \mathrm{~cm}$. females $(5 ; 10.4-13.4)$ : 11.4 , males $(5 ; 8.8-11.6)$ : 10.4 . One female has a thin lateral line, best seen on right side of body. Males with two, sometimes three spots (Fig. 2a-c). Males always with a caudal line, sometimes with a weak body line. Sometimes the spots are nothing more than thickened lines. Basal caudal fin pigmentation is present in one examined male, in others similar markings are found.

UMMZ 158717 (30 of 445), Venezuela, Lagoon $3 \mathrm{~km} \mathrm{~W}$ of Cumaná, 26-03-1939, coll. F.F. Bond. Average length females (5; 25.9-30.4): $28.4 \mathrm{~mm} \mathrm{SL}$, males (5; 17.1-18.0): $17.4 \mathrm{~mm}$ SL. Average least depth caudal peduncle females (5; 11.4-13.7): 13.0, males $(5 ; 15.0-17.0): 16.1$. This population is seemingly more coloured than UMMZ 158720 or UMMZ 158704. Males have a spot in the anterior half of the body or more centrally, and have a spot in C. All males have a varied pattern of lines and bands, bordering brighter areas. Although most unpaired fins are badly damaged, some males exhibit caudal fin patterns resembling Ferrugineus (cf. Winge, 1922; here reproduced as Fig. 7), i.e., a crescent of pigment spots at the caudal base.

UMMZ 158723 (30 of 402), Venezuela, $12 \mathrm{~km}$ northwest of Cumanacoa, $45 \mathrm{~km}$ southeast of Cumaná, tributary to Río Manzanare, 26-03-1939, coll. F. F. Bond. Average length females (530.3-40.7): 34.4 mm SL, males (5; 19.0-21.8): $20.7 \mathrm{~mm} \mathrm{SL}$. Average least depth caudal peduncle females (5; 13.3-15.2): 14.2, males (5; 16.3-18.5): 17.5. The pigmentation in this population is comparable with UMMZ 158717, but darker. No Ferrugineus caudal fin pattern was observed.

UMMZ 158729 (30 of 822), Venezuela, Caracas, Río Guaire, Quebrada Cano, la Florida, 10-01-1939, coll. F. F. Bond. Average length females (5; 26.6-30.7): $29.1 \mathrm{~mm} \mathrm{SL}$, males (5; 18.725.1): $21.2 \mathrm{~mm}$ SL. Average least depth caudal peduncle females (5; 12.8-15.0): 14.0, males (5; 13.9-16.1): 15.2. Males have a varied number of spots (Figs. 5a-e), sometimes differing markedly on left side (Fig. 4a) and right side (Fig. 4b). Pigmentation is also dominated by horizontal lines and bright areas (Figs. $4 c-d$ ), which is reduced in some specimens (Fig. 4e). Most specimens have a variegated caudal fin pattern.
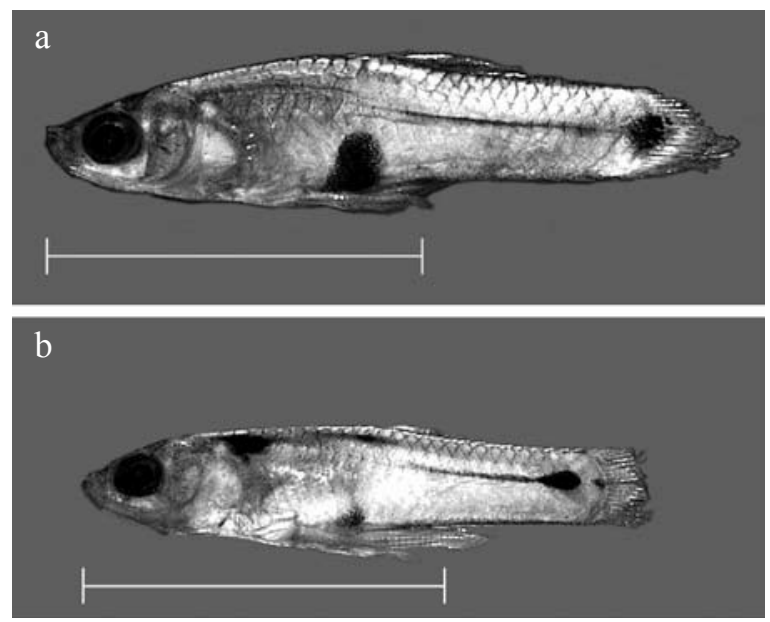

Fig. 2a-b (Photographs by J. v. Arkel). Pigmentation patterns of male guppies from Río Charichapo, Venezuela (UMMZ 158711). Scale is $1 \mathrm{~cm}$. 
UMMZ 158730 (75), Venezuela, Río Mariara, $12 \mathrm{~km}$ west of Maracay, 12-01-1939, coll. F. F. Bond. Average length females (5; 22.5-24.6): $23.5 \mathrm{~mm} \mathrm{SL}$, males (5; 13.4-17.1): 14.9 $\mathrm{mm}$ SL. Average least depth caudal peduncle females $(5 ; 12.4-$ 13.8): 13.3, males $(5 ; 11.7-15.2)$ : 12.9. One female with heavy pigmented fore body. Smaller males all have caudal stripes and two or three spots, larger specimens have less pigment. Two larger males (15.4 $\mathrm{mm}$ and $16.5 \mathrm{~mm}$ ) have very little pigment and immature gonopodia.

UMMZ 158736 (30 of 259), Venezuela, $40 \mathrm{~km}$ west of Puerto Cabello, Río Urama, tributary to Río Yaracuy, 26-01-1939, coll. F. F. Bond. Average length females (5; 21.6-23.0): $22.3 \mathrm{~mm} \mathrm{SL}$, males (5; 14.1-15.5): $14.5 \mathrm{~mm}$ SL. Average least depth caudal peduncle females $(5 ; 13.0-14.8)$ : 14.0, males (5; 12.8-16.6): 14.8. Most males have a shoulder spot, with a spot present ranging from mid-body, to caudal base (Figs. 5a-d). Caudal stripe thin or absent.

ZMA 120.725 (7), Venezuela, Well Cipare, $2.85 \mathrm{~km}$ from Guaibacoa, $3.2 \mathrm{~km}$ on side road Sierra de San Luiz, coll. J.H.

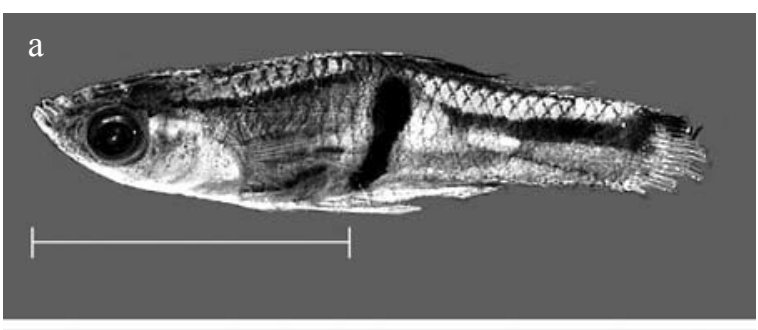

b
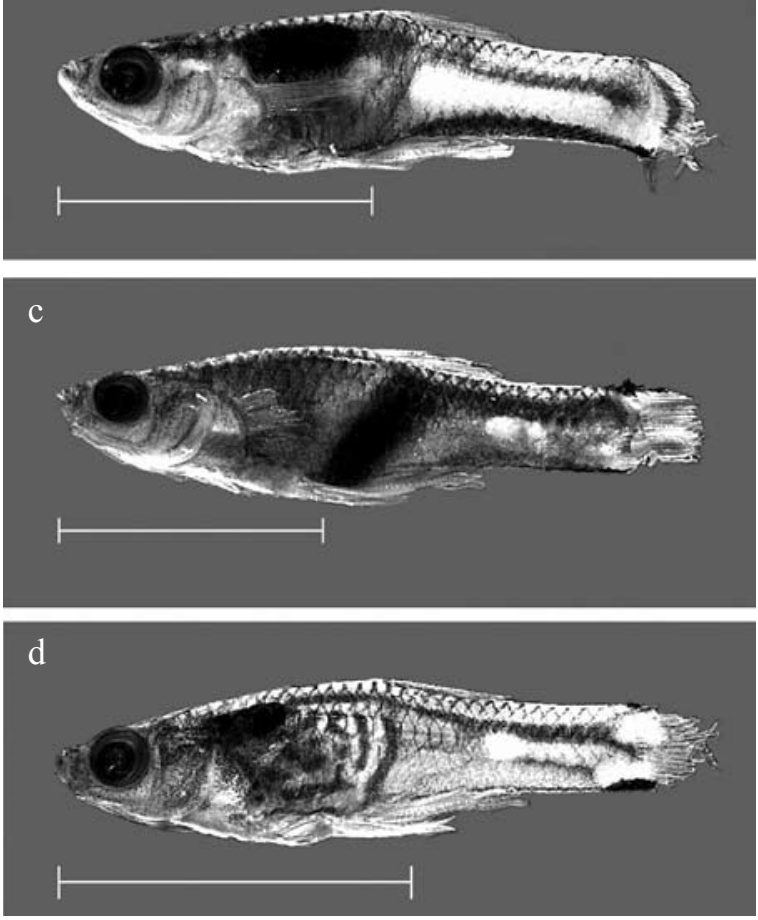

Fig. 3a-d (Photographs by J. v. Arkel). Pigmentation patterns of male guppies from the Paría Peninsula, Venezuela (UMMZ 158715). Scale is $1 \mathrm{~cm}$.
Stock, 1982. One male $(20 \mathrm{~mm})$ with a spot on the anterior part of the body and one at midsection. Caudal peduncle lateral pattern, caudal fin pattern.

ZMA 100.595 (1 ex.), Venezuela, Isla de Margarita, Porlamar, coll. P. Wagenaar Hummelinck, 17-07-1936. One pale male. Body spot at dorsal fin base, one at caudal fin base.

ZMA 123.631 (34), Venezuela, Isla de Margarita, Toma de agua de Encañado, coll. P. Wagenaar Hummelinck, 13-07-1936.
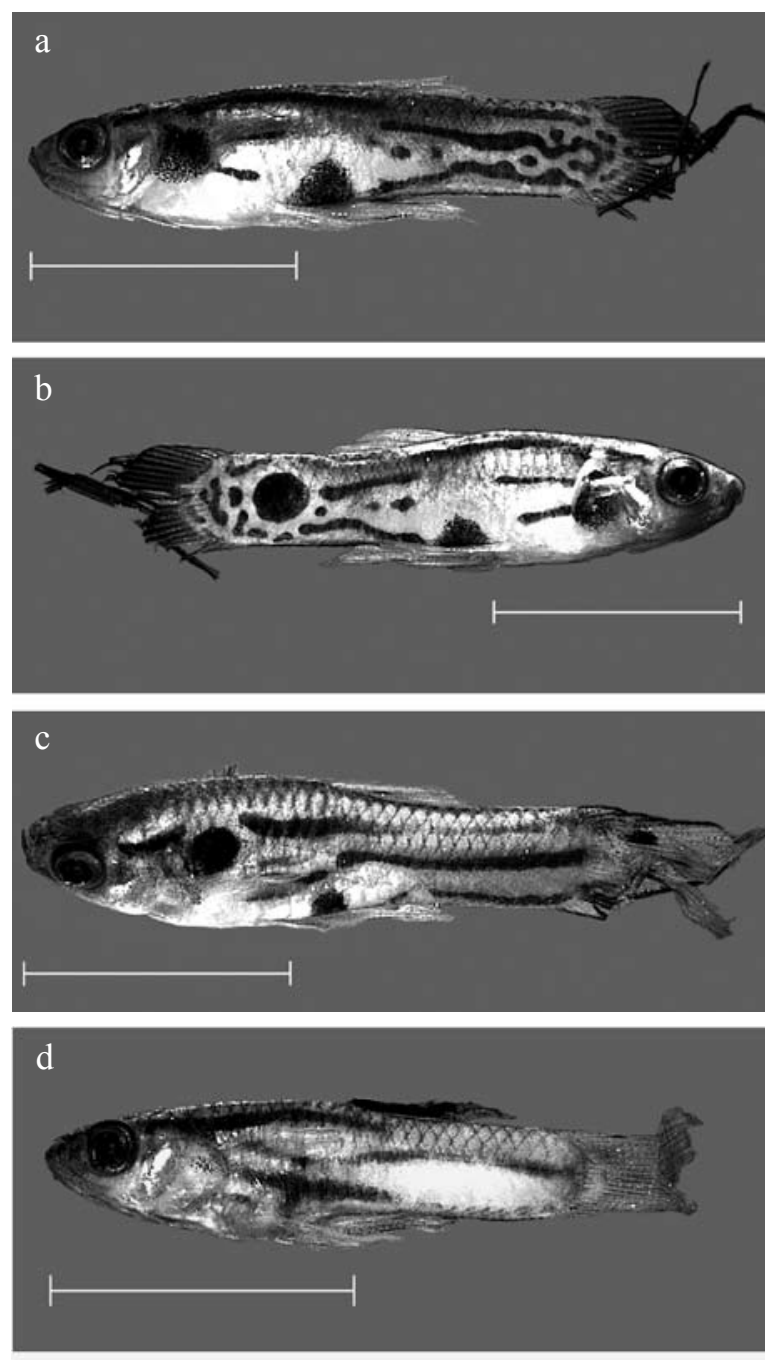

e

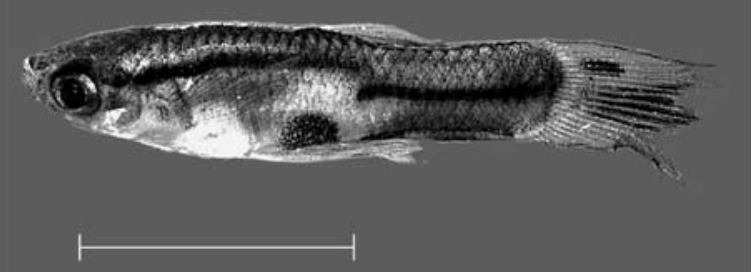

Fig. 4a-e (Photographs by J. v. Arkel). Pigmentation patterns of male guppies from Río Guaire, Venezuela (UMMZ 158729). Scale is $1 \mathrm{~cm}$. 

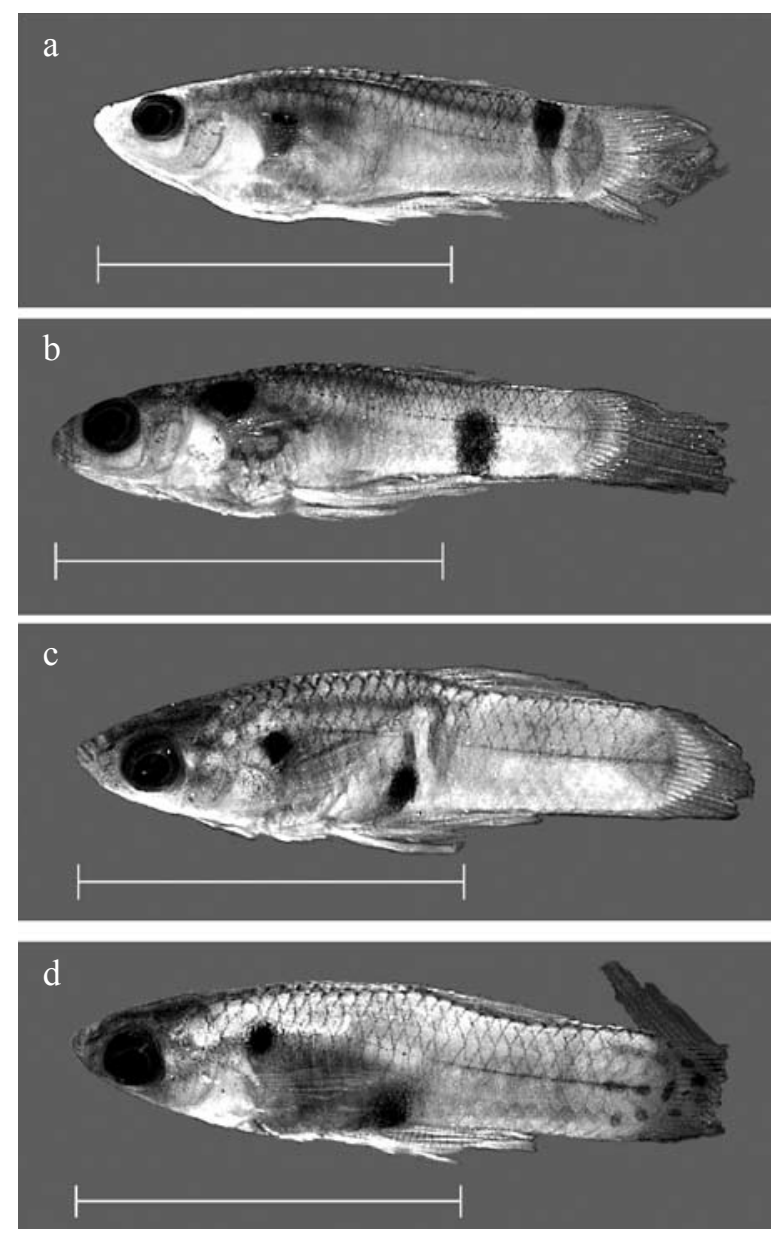

Fig. 5a-d (Photographs by J. v. Arkel). Pigmentation patterns of male guppies from Río Urama, Venezuela (UMMZ 158736). Scale is $1 \mathrm{~cm}$.

The males have spots on the anal base, caudal fin base with pigmentation pattern.

ZMA 123.632 (6), Venezuela, Isla de Margarita, Toma de agua de Tacarigua, coll. P. Wagenaar Hummelinck, 11-08-1936. Three subadult males, pale. Spots on the anterior part of the body and midsection.

ZMA 123.634 (46), Venezuela, Isla de Margarita, Asuncion, Río Asuncion, coll. P. Wagenaar Hummelinck, 11-05-1936. Males are multi-spotted with a vertical pattern on caudal peduncle. Caudal fin has upper margins, lower margins, midsections or both margins coloured, or is even completely coloured. Some females with spots on caudal fin base or on caudal fin.

ZMA 123.635 (31), Venezuela, Isla de Margarita, Asuncion, Río Asuncion, coll. P. Wagenaar Hummelinck, 03-07-1936. Dark specimens, including females.

ZMA 119.916 (20), Guyana, East Coast Demarara, Ogle, coll. M. Temassar, 27-01-1987. Pale specimens. Males with midsection spot, one or two spots on caudal fin base.

ZMA 119.918 (16), Guyana, East Coast Demarara, Industry, coll. M. Temassar, 28-01-1987. Multi-spotted males with two to four spots, vertical stripes on caudal peduncle. Caudal fin pattern present.

ZMA 115.037 (4), Guyana, Canal to Demarara River, near Georgetown, coll. P. de Rham, 11-10-1976. Anterior spot, caudal spot, and a small spot in the midsection.

ZMA 109.626 (1 ex. [ex Carnegie museum]), Guyana, Georgetown trenches, det. C. H. Eigenmann, no further data. Male with spots on anterior part of body and caudal peduncle. Vertical pattern caudal peduncle.

ZMA 100.527 (16), Suriname, District Marowijne, coll. P. Florschutz, December 1952. 16 Multi-spotted males with lateral patterns and caudal fin patterns

ZMA 115.116 (1 ex.), Suriname, Marowijne district, Pankoekoe Creek, coll. M.P. Panday, June 1974.

Body with anterior spot and caudal fin base spot. Lower margin caudal fin pigmented.

ZMA 119.999 (10), Suriname, Paramaribo, coll. W.C. v. Heurn, August 1911. Males are multi-spotted, spots on anterior part of body and midsection, caudal peduncle and caudal fin base.

ZMA 120.724 (4), Barbados, Well of Thicket, coll. J.H. Stock, 10-06-1978.

One multi-spotted male, spots on anterior part of body, midsection, caudal fin base. Caudal fin pattern present.

ZMA 109.627 (5, ex Carnegie museum), Barbados, det. C.H. Eigenmann, no further data. Three males, dark. Spots on midsection and anterior part of body, caudal fin pattern present.

ZMA 120.727 (78), Barbuda Island, coll. P. Wagenaar Hummelinck, 09-05-1955.

Dark specimens. Males are multi-spotted with a caudal fin pattern. ZMA 120.006 (27), Pacific Ocean, Cook Islands, Vai Momoiri, Sink hole in Makatea, coll. N.W. Broodbakker, 08-081986. Males have spots in midsection, anal fin base and caudal fin base.

\section{Collection data of the 2002 expedition}

In the summer of 2002, Poeser and Kempkes stayed in a posada near Cariaco, on the highway to Casanay. From this base daily trips were made to localities in the surroundings, guided by a local taxi driver, Mr. Luis Palacio, who grew up in the region. Mr. Palacio thus provided much information, e.g., the names of the waters, villages, etc. At nearly all localities in the proximity of the posada guppies were abundant, easy to catch with a simple dipping net. The samples were divided later into 'Campoma' guppies (Poecilia wingei n. sp.) and common guppies (Poecilia reticulata), hereafter indicated as such.

13-07-2002. Station 1: Road from Cariaco to Carúpano, bridge at the division of Laguna Campoma and Laguna Buena Vista, ca. $3 \mathrm{~km}$ north of Cariaco. Male guppies had a melanophore pattern as in UMMZ 158715. All other colours much enhanced by metallic sheen, they are brilliant. Also females exhibited a more brightly sheen on their bodies, compared to the guppy females we were used to. Some other, larger fish, probably cichlids, were present. A collection of guppies was made, deposited in ZMA 123.636 (Campoma guppy).

13-07-2002. Station 2: Irrigation ditch ca. 50 meters from the road from Cariaco to Carúpano, ca. $2 \mathrm{~km}$ north of Cariaco. Gup- 
pies as in station 1, which were deposited in ZMA 123.637 (Campoma guppy).

13-07-2002. Station 3: Same irrigation ditch as locality 2 at the outskirts of Cariaco. Same guppies as in stations 1 and 2 (Campoma guppy). No guppies were deposited.

13-07-2002. Station 4: Bridge over wide stream next to road from Cariaco to Chocopata, ca. $3 \mathrm{~km}$ from Cariaco. Same guppies as in stations 1-3, deposited in ZMA 123.638 (Campoma guppy). Also fish of the genus Rivulus was collected, deposited in ZMA 123.639

13-07-2002. Station 5: Small stream at Heullo de Cariaco, small village at the Golfo de Cariaco. Common guppies, viz., melanophores in spots, little trace of metallic sheen, deposited in ZMA 123.640 (Common guppy). In this small biotope, a remarkable collection of mollies (Poecilia koperi Poeser, 2002; ZMA 123.6341), Rivulus sp. (ZMA 123.642), Gobiidae gen. sp. indet. (ZMA 123.643), Poecilia picta (ZMA 123.644) and a shrimp was made.

13-07-2002. Station 6: Waterfall El Cordon, ca. $5 \mathrm{~km}$ west of Cariaco. Large common guppies, males ca. $3 \mathrm{~cm}$ TL, females 4-5 cm TL. Variegated colour patterns, with large metallic, silvery blotches. Also a cichlid predator was collected. No specimens were deposited.

14-07-2002. Station 7: Río de Oro, at the entrance of Aguas de Moises. Small river with many bends. Guppies as in stations 1-4 (Campoma guppy), together with characid fish, Crenicichla sp., Cichlasoma sp., a rivulid fish, and crabs. No specimens were deposited.

14-07-2002. Station 8: Junction of Río Catuaro and Río Santa Lucia, tributary to Río San Juan, tributary to Río Orinoco, ca. 10 $\mathrm{km}$ south of Casanay. Common guppies, chromatophores in spots, no extensive metallic sheen. No specimens were deposited.

14-07-2002. Station 9: Río Tonoro (= Río Domingo), tributary to Río San Juan, tributary to Río Orinoco, ca. $20 \mathrm{~km}$ south of Casanay. Guppies like in locality 8 (Common guppy). No specimens were deposited.

14-07-2002. Station 10: Río Grande, at Río Grande, tributary to Río San Juan, tributary to Río Orinoco, ca. $25 \mathrm{~km}$ south of Casanay. Guppies like in stations 8 and 9 (Common guppy). No specimens were deposited.

15-07-2002. Station 11: Small ditches, parallel to the road from Cariaco to Carúpano, ca. $3 \mathrm{~km}$ west of Carúpano. Guppies with a mix of characters, i.e., melanophores concentrated in spots, with other colours brightly metallic (as in stations 1-4, 7). These fish were syntopic with a sailfin molly, identified as Poecilia latipinna (LeSueur, 1821). The guppies were deposited in ZMA 123.645 (Campoma guppy), the sailfins in ZMA 123.646.

15-07-2002. Station 12: Laguna north of the road from Cariaco to Carúpano (= seaside), ca. $2.5 \mathrm{~km}$ west of Carúpano. Guppies like in station 11, deposited in ZMA 123.647 (Campoma guppy).

15-07-2002. Station 13: Laguna south of the road from Cariaco to Carúpano (= land side), ca. $2 \mathrm{~km}$ west of Carúpano. Guppies like in stations 11 and 12 (Campoma guppy), but much less colourful. No specimens were deposited.

15-07-2002. Station 14: Río El Pilar, bridge on the road from Carúpano to El Pilar, ca. $15 \mathrm{~km}$ southeast from Carúpano. Common guppies, like in stations 8-10. No specimens were deposited.

15-07-2002. Station 15: Río Casanay, at Guarapiche. Guppies as in stations 11 and 12 were deposited in ZMA 123.648 (Campoma guppy).
16-07-2002. Behavioural studies at station 7. Nearby, in a stream close to the road from Cariaco to Casanay, ca. $4 \mathrm{~km}$ from Casanay, we discovered another stream containing guppies like in stations 1-4, 7 (Campoma guppy).

17-07-2002. Several locations north of the Golfo de Cariaco. These locations are not noted as stations, they did not yield any guppies. One molly, viz., Poecilia koperi, was collected in Laguna de los Patos and deposited in ZMA 123.649.

18-07-2002. Behavioural studies at stations 14. Guppies like in stations 1-4, 7 (Campoma guppy), near the Posada Elvira, on the road from Cariaco to Casanay, ca. $2 \mathrm{~km}$ from Cariaco.

\section{Systematic section}

\section{Poecilia (Acanthophacelus) wingei $\mathrm{n} . \mathrm{sp}$.}

Type material. Holotype. ZMA 123.704 (male), Venezuela, Estado Sucre, Paría Peninsula, ca. $3 \mathrm{~km}$ north of Cariaco, bridge on the road from Cariaco to Carúpano, division between Laguna Buena Vista and Laguna Campoma, coll. F.N. Poeser, M. Kempkes, and L. Palacio, 13-VII-2002. Allotype. ZMA 123.705, (female) same data as ZMA 123.704. Paratypes. ZMA 123.636 (18), same data as ZMA 123.704; ZMA 123.637 (67), Venezuela, Paría Peninsula, irrigation ditch ca. 50 meters from the road from Cariaco to Carúpano, coll. F.N. Poeser, M. Kempkes, and L. Palacio, 13-VII2002; ZMA 123.638 (25), Venezuela, Paría Peninsula, ca. 3 km from Cariaco, bridge over wide stream beside road from Cariaco to Chocopata, coll. F.N. Poeser, M. Kempkes, and L. Palacio, 13VII-2002; ZMA 123.645 (7), Venezuela, Paría Peninsula, ca. 3 km west of Carúpano, small ditches, parallel to the road from Cariaco to Carúpano, coll. F.N. Poeser, M. Kempkes, and L. Palacio, 15VII-2002; ZMA 123.647 (38), Venezuela, Paría Peninsula, ca. 2,5 $\mathrm{km}$ west of Carúpano, laguna north of the road from Cariaco to Carúpano (= sea side), coll. F.N. Poeser, M. Kempkes, and L. Palacio, 15-VII-2002; ZMA 123.648 (10), Venezuela, Paría Peninsula, Río Casanay, at Guarapiche, coll. F.N. Poeser, M. Kempkes, and L. Palacio, 15-VII-2002; UMMZ 158715 (30 paratypes of 585), Venezuela, Paría Peninsula, stream $35 \mathrm{~km}$ west of Carúpano, 28-03-1939, coll. F.F. Bond.

Description of the types. The holotype is a male, 14.3 $\mathrm{mm}$ SL, with a black band at the most anterior part of the caudal peduncle (cf. Fig. 3a, b). On the right side of the caudal peduncle are two elongate and interconnected metallic spots. Body scales contain many melanophores, darkening the body and forming a vague spot between the ventral and pectoral fins. The pigmentation on the left side is like the right side, but with the vague spot elongate as a band, bordering a metallic body colour. This male has a definite caudal fin pattern, with a slightly enlarged and dark upper margin. The upper and central section shows small black spots, whereas the lower margin is pigmented at the base, i.e., a thin black line on the lower margin 
of the fin and a white area around a black spot just above this margin. The gonopodium contains remarkably many melanophores, also extending to the gonopodial palp.

All other diagnostic features are as mentioned in the characterisation of the subgenus.

The allotype is a slender female, $14.1 \mathrm{~mm}$ SL. The unpaired fins and the body with many melanophores, whereas melanophores are concentrated along the margins of the scales. No further specific markings are present. Females of $P$. wingei are indistinguishable from those of $P$. reticulata, with the possible exception of a slight metallic sheen in life specimens.

The paratopotypes are 12 females and juveniles without specific pigmentation, 4 subadult males with one or two metallic spots on the body and caudal peduncle. These males have a caudal stripe and a basal spot on the caudal peduncle. The two remaining males show more developed markings. The smaller of these two has an anal black spot and black horizontal bands on body and caudal peduncle, bordering a lighter, mostly metallic area. The caudal fin pigmentation is more or less an extension of the body pigmentation, i.e., a central lighter area bordered by a thin black line. The larger of the two adult males is coloured like the holotype, but with a thinner blotch halfway the body. This band splits the anterior of the two metallic spots. The anterior part of the body is very dark.

One female has a thin lateral line. Males do not have spots, but blotches from the origin of the gonopodium to under the dorsal fin (Figs. 4a-d). Anterior side of the body sometimes has broken spots, or little horizontal lines. One or two bands over the caudal peduncle, caudal peduncle with a brighter area or a bright spot. The gonopodial palp on ray 3 exceeds the tip, but is seemingly smaller in this population than in others.

The gonopodia from two of the males (Fig. 3b-c) are also figured (Fig. 6).

Diagnosis. Poecilia wingei is a small species, with males measuring up to about $15 \mathrm{~mm} \mathrm{SL}$ and females up to $20 \mathrm{~mm}$ SL, and with a distinct sexual dimorphism, with polychromatic males and uniform females. Meristic data. A. 9; D. 6-7; C. 12-14; LLS. 25-27; CPS. 14 . The gonopodium has a retrorse hook on ray 5 , but not on ray 3 . The fleshy palp on ray 3 is extending beyond the tip. The ventral spines on ray 3 are large, resulting in a bulb-like appearance of the gonopodial tip. The dorsal bulbs on ray $4 \mathrm{a}$ are much smaller than the spiny dorsal extensions on ray $4 \mathrm{p}$.

Comparison. Poecilia wingei differs from most species of Poecilia by the following characters. The gonopodial palp extends clearly beyond the tip of the gonopodium. The gonopodium also lacks a terminal hook at ray 3, present in the short finned and sailfin mollies and in Psychropoecilia. With the exception of Micropoecilia, none of the subgroups of Poecilia, viz., the $P$. sphenops species group, the $P$. latipinna species group, the $P$. caucana species group, Curtipenis and Psychropoecilia, have polychromatic males. It also differs from most species groups in the number of scales around the caudal peduncle, i.e., 14 vs. 16 or more, sharing this characteristic only with the $P$. caucana species group and Micropoecilia. Females are further distinguished from all other species groups by the unique combination of nine anal fin rays and less than eight dorsal fin rays.

Its closest relative is the common guppy, $P$. reticulata, sharing identical meristic data, but differing by its enhanced metallic body pigmentation. This brightness in body pigmentation is also noticed in the females of $P$. wingei. Moreover, in the zone adjacent to the distribution area of the common guppy, $P$. wingei males exhibit a unique melanophore pattern, viz., a large band in the midsection of its body. The importance of this feature, i.e., the spatial distribution of melanophore patterns, is decisive for its recognition as a valid species (see below).

UMMZ 158715 was examined and compared to the common guppy (see above). Average length females (5; 26.9-30.4): $29.0 \mathrm{~mm} \mathrm{SL}$, males $(5$; 18.8 21.3): $19.6 \mathrm{~mm}$ SL. Average least depth caudal peduncle females $(5 ; 10.4-13.4)$ : 11.5 , males $(5$; 10.6-13.2): 11.6.

Distribution. The Campoma guppy occurs in fresh waters in the Campoma- and Buena Vista Lagoons, unto Carúpano.

Etymology. We dedicate this species to Dr Øjvind Winge, born in May 1886, died in April 1964. He was head of Department of Physiology, Carlsberg laboratory (1933-1956), and was not only the father of "genetic engineering" (Szybalskia, 2001), but also described many colour patterns and the genetics of 
sex-determination in the common guppy as a result of extensive breeding experiments. His work provided the basis for understanding the colour polymorphism in guppies in general (answering to the question posed by Houde [1997: 5]) and the means for recognition of character displacement between the common guppy and the Campoma guppy in particular.

Hypothetical origin. The area of distribution of this new species invites speculation to its origin. It is separated from the Orinoco River and the common guppy by the Cordilleras de la Costa, it is, therefore, obvious to propose that the upraise of these mountains separated the shared ancestor of both species. The Campoma guppy is restricted to the coastal side of the Cordilleras, whereas the common guppy initially occupied the landside, or Orinoco side, of Venezuela. The common guppy somehow re-migrated to the coastal areas, maybe through areas near present-day Barcelona, where rivers with a Caribbean drainage originate next to rivers of the Orinoco drainage. The Campoma guppy managed to keep its specific integrity in the base of Paría through sexual selection based on character displacement in male body coloration (cf. Houde, 1997). Differences in male coloration might be caused by accumulation (or mutation) of genes responsible for iridocytes, i.e., the metallic colours, accentuated by the black midsection band on the males in the probable zone of sympatry, the Campoma region. Differentiation in pigmentation within the type series suggests that the midsection band develops later in life.

\section{Characterisation of the genus Poecilia}

The genus Poecilia was defined by three synapomorphies (Poeser, 2003: 119, 137): (i) Serrated serrae subdistally on gonopodial ray 3; (ii) A protruding hook, distally on gonopodial ray 5p; (iii) Hook found distally on gonopodial ray 3 . The phylogenetic analysis on which these conclusions were based, compared the genera of the Poeciliini (sensu Rosen and Bailey, 1963) with Brachyrhaphis Regan, 1913, lumping all subgroups of Poecilia in an extensive polytomy. This prompted Poeser (2003, chapter 9) to consider the $P$. reticulata species group phylogenetically indefinable as a subgenus. A re-examination of eleven characters strictly applicable to Poecilia was made, this time including all species (cf. Poeser,
2003, chapter 11). To root the tree, Alfaro cultratus (Regan, 1908) was chosen as outgroup.

The analysis rendered a surprising arrangement of taxa. At the base, the three Hispaniolan species of Poecilia are the sistergroup of all remaining species. These species are classified according to the available subgeneric names, rendering them $P$. (Curtipenis) elegans (Trewavas, 1948), P. (Psychropoecilia) dominicensis (Evermann and Clark, 1906) and $P$. (Psychropoecilia) hispaniolana Rivas, 1978. Much to our surprise, also $P$. (Acanthophacelus) reticulata was allocated at the base, separating $P$. reticulata from its South American congeners. The species described herein as new shares these characters. Therefore, we conclude that the phyletically closest relatives are not among the geographically closest relatives. Since both species of guppies are less related to $P$. vivipara Bloch and Schneider, 1801 and to $P$. parae, we re-instate subgeneric distinctions in Poecilia to emphasise this distinction. In the cladogram (Poeser, unpublished), Acanthophacelus is closest related to the Central American mollies, as is Poecilia (Poecilia) vivipara, but they are not each other closest relatives (confirming the phylogenetic relationships within Poecilia based on mitochondrial DNA [Ptacek and Breden, 1998]). Micropoecilia spp. are closely related to $P$. vivipara.

\section{Characterisation of the subgenus Acanthophacelus}

The allocations in species groups are largely prompted by the gonopodial features and number of dorsal fin rays (Table IV). These differences are geoclinal for the species of the subgenus Poecilia (cf. Poeser, 2003, chapter 5), combining the $P$. vivipara species group with the $P$. latipinna and the $P$. sphenops species groups. The remaining species groups are identifiable by these characters, yielding the following characterisation of Acanthophacelus:

Meristic data. A. 9; D. 6-7; C. 12-14; LLS. 25-27; CPS. 14.

Both species are small with marked sexual dimorphism in size and in pigmentation. Mature males are about 14 to $21 \mathrm{~mm} \mathrm{SL}$, females are about 20 to $38 \mathrm{~mm}$ SL. Females are relatively more slender, least depth of the caudal peduncle averaging from 10 to $16 \% \mathrm{SL}$, whereas males are slightly more stout, from 10 to $18 \%$ SL. Females are generally without markings, except for a reticulate pattern of melanophores along the scales margins. Males always have black markings in 


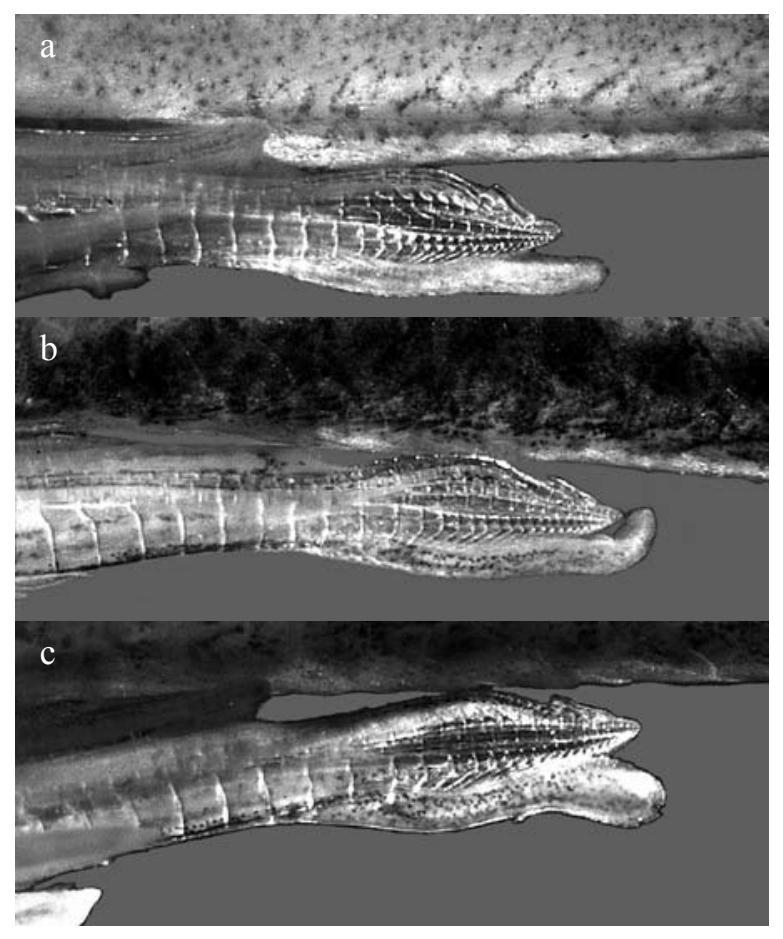

Fig. 6a-c (Photographs by J. van Arkel), detailed photographs of gonopodia. (a) Poecilia reticulata, gonopodium of specimen in Fig. 1a; (b, c) Poecilia wingei, gonopodia of specimens in Figs. 3b, c.

their variegated colour pattern. While females have no diagnostic markings on their silver grey to brownish bodies, males have patterns that are hard to describe. Within a population no male is exactly the same as another. Although this is largely true for male specimens within one population, some generalities are apparent between populations:

Poecilia reticulata: Sometimes a population consists of males with only one spot, e.g., UMMZ 158730 and UMMZ 158753. Most populations contain males that are multi-spotted, e.g., UMMZ 158704, UMMZ 158706, UMMZ 158711, UMMZ 158717, UMMZ 158720, and UMMZ 158723 (Figs. 1, 2, 5). Occasionally, males exhibit a horizontal line on the body, and/or on their caudal peduncle. A vertical elongated band may be present on the caudal peduncle, e.g., UMMZ 158736 (Fig. 4).

Poecilia wingei: A large vertical band is sometimes present in the midsection of the body, at the anterior part of the caudal peduncle, e.g., UMMZ 158715 (Fig. 3). Populations near Carúpano contain males that are multi-spotted, like in $P$. reticulata.
These patterns concern preserved melanophores. Life colours also include differently coloured spots, e.g., red, orange, yellow, blue, green and blue, dull or iridescent spots and patches, whereas also red horizontal lines are not uncommon. Some individuals exhibit only a single colour, e.g., red or green, whereas most individuals have colour patterns combining spots and patches of different colours. Also the unpaired fins, except the gonopodium, can have colours, sometimes with an elongation of the upper or lower caudal fin lobe. We are not aware of any study that correlates specific colour patterns to particular areas, although several studies have shown correlation between colour patterns and ecological factors, e.g., predation pressures (Reznick, 1982, 1983; Reznick et al., 1996a, 1996b, 1996c; Albers, 2000), and food regimes (Robinson and Wilson, 1995). A recent study (Alexander and Breden, 2004) that shows this correlation is discussed below. The genetic basis of these spots has been investigated since Schmidt (1920) and Winge (1922).

The occurrence of a wide polymorphy of melanophore patterns conflicts with the genetic mechanism proposed by Winge (1922, 1927; Fig. 7) which only allows for a moderate amount of variation in these patterns. However, other genetic mechanisms have been proposed (Turing, 1952; Murray, 1988) explaining the variation in the observed patterns. One characteristic of this alternative explanation explains why bodies are never striped when the caudal is spotted, which is true for all guppies examined. It also explains the differences in spot size, e.g., correlated with predation regiments. The genetics of this mechanism is highly speculative, and therefore not discussed herein.

Comparison of the colour patterns between the subgenera Acanthophacelus and Micropoecilia

Generally, some similarities between melanophore patterns in the guppy and in the species of Micropoecilia (cf. Meyer, 1993) are observed. A number of guppy populations have colour patterns like those found in the species of Micropoecilia. A spot on the caudal base combined with a pigmented upper margin of the caudal fin, found in many populations of $\mathrm{Mi}$ cropoecilia, was named $P$. reticulata 'Lineatus' (cf. Winge, 1927). The large red and black spots are present in nearly all guppy populations, as well as in P. parae 'amazonica' and P. picta (Poeser, 2003, chapter 11). 
Table IV. Characterisation of the subgenera in Poecilia.

Poecilia vivipara represents Poecilia; P. sphenops and P. latipinna represent Mollienesia; P. dominicensis represents Psychtopoecilia; P. elegans represents Curtipenis; P. parae represents Micropoecilia; P. reticulata represents Acanthophacelus; P. caucana represents Allopoecilia.

\begin{tabular}{|c|c|c|c|c|}
\hline Species group & Serrae on ray 3 & Hook on ray 3 & Hook on ray $5 p$ & Number of dorsal fin rays \\
\hline Poecilia sphenops & + & + & + & $8-11$ \\
\hline Poecilia latipinna & + & + & + & 12 or more ${ }^{1}$ \\
\hline Poecilia dominicensis & - & + & + & $8-11$ \\
\hline Poecilia elegans & + & - & + & $8-11$ \\
\hline Poecilia vivipara & + & -2 & -3 & $7-11$ \\
\hline Poecilia parae & + & -4 & -5 & 8 \\
\hline Poecilia reticulata & + & - & + & $6-7$ \\
\hline Poecilia caucana & + & $+/-^{6}$ & + & 8 \\
\hline
\end{tabular}

1 Poecilia latipunctata seems a noticable exception to this. Molecular data clearly indicate close relations with the $P$. latipinna species group (12-20 dorsal fin rays), although it does not have more than 11 dorsal fin rays (cf. Poeser, 2003).

2 This character is "reduced to absent" in this species group (cf. Poeser, 2003).

3 This character is "reduced to absent" in this species group (cf. Poeser, 2003).

4 This character is "reduced to absent" in this species group (cf. Poeser, 2003).

5 This character is "reduced to absent" in this species group (cf. Poeser, 2003).

${ }^{6}$ Frequently much reduced in this species group (cf. Poeser, 2003)
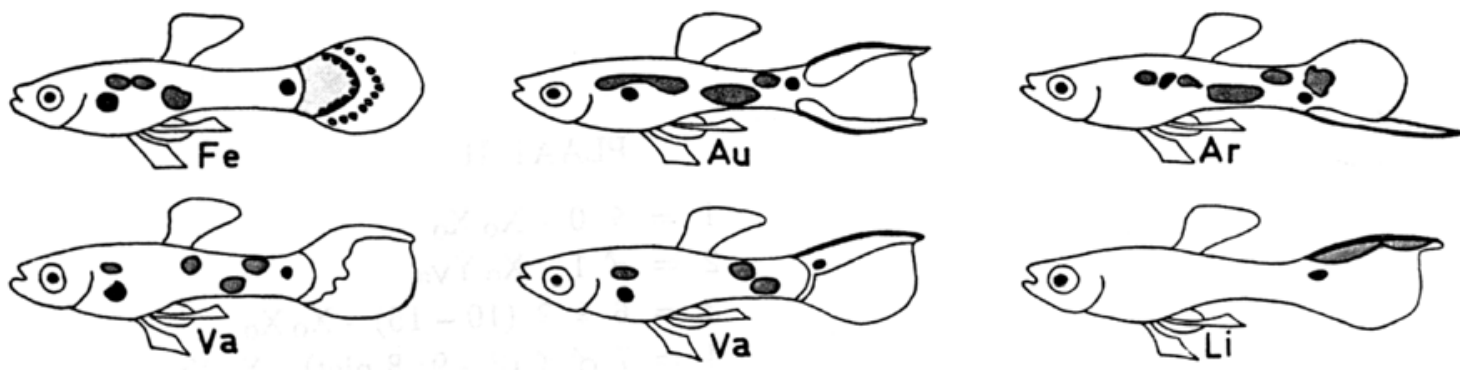

Fig. 7. Drawings of guppy phenotypes (after Westerhof, 1960) Ferriguneus, Auratus, Armatus and Variatus represent 'multi-spotted' males with different caudal fin patterns, Lineatus only indicate the caudal fin pattern.

There can be a bright area on the caudal peduncle, margined by heavily pigmented bars (Figs. 3-4), like in P.parae 'melanzona' (Fig. 8). Two explanations are possible. If these patterns occur sympatrically, it might be that these reflect better shoaling possibilities or adaptations to similar environmental demands. If these patterns do not co-occur, a special form of character

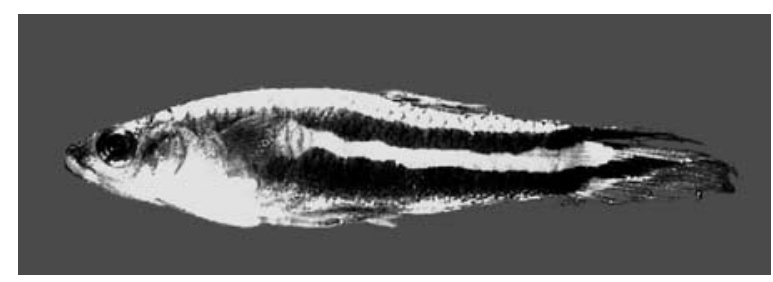

Fig. 8. Habitus of Poecilia parae 'melanzona'. The pigmented bars on the caudal peduncle resemble the phenotypes of guppies shown in Figures $3 \mathrm{c}$ and $4 \mathrm{c}$. displacement (cf. Poeser, 1995, 1998; present paper) might be present. Examination of these patterns, both genetically and bio-geographically, e.g., correlated to mimicry or character displacement, therefore, is a promising field of investigation, possibly explaining the occurrence of these patterns in wild guppies and in Micropoecilia.

Gonopodia. The gonopodium of both species of guppies (cf. Meyer, 1993; Fig. 6) has a retrorse hook on ray 5 , but not on ray 3 . The fleshy palp is much elongated, extending well beyond the tip. The ventral spines on the 3rd gonopodial ray are large, giving the gonopodium a bulb-like appearance. Both ray $4 \mathrm{a}$ and ray $4 \mathrm{p}$ have dorsal spines, the spines on $4 \mathrm{a}$ are much smaller than on $4 \mathrm{p}$.

Habitat. Guppies are known to inhabit a wide vari- 
ety of habitats with temperatures ranging from 18$30^{\circ} \mathrm{C}$. They are not adapted to special biotopes but do not occur in purely marine environments.

Distribution area. The common guppy is presently circumtropical. However, it is believed to occur naturally only in the northeastern part of South America and on the Lesser Antilles (Fig. 9). We consider only the mainland areas of Venezuela, east of Lago de Maracaibo, further east to the Guiana's, the adjacent part of Brazil, Para district, and upstream the Amazon river (Rio Solimões) as its natural area of distribution. Based on data presented in the discussion section, the occurrence on Trinidad is undisputed. The island of Barbados (cf. Boulenger, 1912) is not considered part of its natural range (Poeser and Isbrücker, 2002).

\section{Spatial distribution of the phenotypes of the freshly collected guppies}

Life colours of the Orinoco variety of $P$. reticulata are characterised by one or two black spots, often enhanced by a metallic patch. This morph is named for the guppies from stations 8-10, which eventually are tributaries of the Río Orinoco. Guppies from stations 5 and 14 are similar to these phenotypes and are therefore also classified as Orinoco guppies. These specimens are like most guppies ( $P$. reticulata) examined from the ZMA and UMMZ material.

Guppies caught below the El Cordon waterfall (El Cordon variety, station 6) differ from the Orinoco variety. Not only are they substantially bigger, body colorations are different too. Two specimens (of five collected males) had enormous 'peacock' caudal fins, i.e., a large black spot margined by a bright metallic, silvery blotch. One specimen was without any specific colours, except for exhibiting a metallic silver body. This latter specimen also had an enormous gonopodium, extending almost to the caudal base. The possible origin of the characteristics of this variation is discussed below.

In the areas of stations 11-13, 15 (Carúpano region), the guppies exhibited similar colour patterns as the Orinoco variety, with the addition of metallic polychromatic patterns. Where in the Orinoco guppies the metallic sheen is restricted to areas around the black spots, in $P$. wingei all colours are a brilliant array of metallic colours: red, blue and green to yellow (= gold). Dorsal fin is usually transparent, however, sometimes black or white markings are present.
Caudal fin variegated, i.e., with red or black upper, lower or both margins, or a brownish blotch extending from the caudal base. Females are greyish, with a bright sheen over their bodies.

In the area around stations 1-4, 7 (Campoma region), guppies are found with colours like the Carúpano variety, with addition of a characteristic black midsection of the body. Individual specimens exhibit a black anterior part of the gonopodium, or a fine striped pattern on the anterior part of body, or a completely green body.

\section{Evidence of character displacement}

Character displacement is observed "when the areas of distribution of two species of animals overlap geographically, the differences between them are accentuated in the zone of sympatry and weakened or lost entirely in the parts of their ranges outside this zone (Brown and Wilson, 1956)". Summarising the spatial distribution of the phenotypes, the least variegated guppies (hereafter named type A) are the El Cordon variety, followed by the Orinoco variety that has black spots and some metallic fringes (type B). The Carúpano morph also has black spots, but is brilliantly metallic (type C), whereas the most extensive black and metallic colouring (type D) is found in the Campoma variety.

When plotted on a map (Fig. 10), the distribution of phenotypes shows coherence. The brilliant guppies occur exclusively in the Cariaco-Carúpano region, a valley of marshlands surrounded from south to east by the Cordilleras de la Costa. The northern parts of this region are enclosed by the dry Araya Peninsula and in the west it is bordered by the Golfo de Cariaco. It is from this latter area that $P$. reticulata can enter this territory. In the western part of this region, where $P$. wingei and $P$. reticulata may co-occur, both populations have their most extreme phenotypes, i.e., the Campoma variety of the Campoma guppy and the El Cordon variety of the Orinoco, or common, guppy. In the areas in which these two kinds of guppies do not co-occur the phenotypes are similar: the Carúpano variety of the Campoma guppy seems merely a brilliant version of the Orinoco guppy. Both phenotypes are here characterised by the typical black spots. So, while conspecific genetic variation supposedly would follow an A-B-C-D pattern in colour-type distribution, observed distribution is actually B-A-D-C. This 
represents a clear example of character displacement, leaving little doubt that the Campoma guppy indeed represents a new species.

Character displacement as a pre-copulatory isolation mechanism has already been suggested to have mediated in the speciation of Hispaniolan short fin mollies (Rivas, 1982), short fin mollies from El Salvador (Poeser, 1995) and sailfin mollies (Gabor and Ryan, 2001). The example in guppies is new to science and its characteristics, i.e., easily accessible populations of a species already thoroughly studied and clearly limited geographical dimensions, makes it an almost perfect subject for further studies. The occurrence of this type of speciation was already predicted (Houde, 1997: 55): “... a distinctive guppy population from Venezuela that, at least in laboratory stocks, appears to be monomorphic, but is interfertile with Trinidad guppy populations ... A species-recognition function for colour patterns thus cannot be ruled out..."

The case study of Alexander and Breden (2004), examining this phenomenon, is fully discussed below.

While there is little doubt about the distribution of phenotypes of $P$. wingei, the origin of the El Cordon phenotype ( $=$ P. reticulata $)$, based on only a small collection at one locality, remains the subject of further study. This phenotype can have arisen either by character displacement or by hybridisation.

\section{Behavioural differences between Poecilia reticu- lata and $P$. wingei}

\section{Behaviour of the Common guppy}

Guppies differ from all other species of Poecilia in their mating behaviour (Liley, 1966). Behavioural patterns herein described are personal observations, obtained from the field trip to Venezuela described herein, as well as from an earlier field trip (Kempkes, in 1993) and from aquarium observations. Our studies agree with the observations of other authors on P. reticulata (cf. Houde, 1997). Courtship behaviour in $P$. reticulata proceeds in strict sequential ordered elements (Table III). However, some variation in behaviour was observed when behavioural elements were occasionally skipped by courting males.

In the El Pilar river (Fig. 10) two isolated popula- tions of $P$. reticulata were observed (15-07-2002, from 13.00 to $13.30 \mathrm{hr}$, and 18-07-2002 from 9.40 to 10.10 hr). Both populations occupied about a half square meter and the water was $10-20 \mathrm{~cm}$ deep, and both microhabitats were located near the riverbanks. No fish were observed to enter the fast flowing waters in the midsections of the river. Therefore, the population was found to be relatively constant, with no individuals leaving or entering the community. The action radius of males within the population appeared to be bigger than that of females. In these groups, being 'local populations', some territorial behaviour was observed in which the largest females maintained a bigger individual distance to other larger females. These females reacted to approaches of other females by biting them and chasing them away. Juvenile guppies predominantly inhabited the banks of the river, close to the main population. We think that in the shallow water, young guppies were relatively save from predators. Sexually mature males were continuously near the females of their group. The intra-sexual competition between the males was especially perceptible during the courtship: males constantly tried to disturb the courtship of other males, after which they attempted to court the same female. Female choice is apparent (cf. Houde, 1997), because of energy costs of internal maturation of eggs and the additional costs of swimming around highly pregnant. Furthermore, the supply insemination adds to what the males invest to the reproduction. In a laboratory test, Nicoletto (1993) described that female guppies favour large guppy males. The orange and iridescent colour areas at the bodies of the males are probably indications of the fitness of males. Female choice, combined with the establishment of local populations, should favour genetic drift. When populations remain at more or less the same geographical position, these populations will adapt to the specific requirements of these localities. It has been postulated that sneak copulation alone counteracts possible genetic drift (Magurran, 1998).

\section{Behaviour of the Campoma guppy}

The behaviour of $P$. wingei is new to science and is therefore extensively described. Observations were made on the 14th, 16th and 18th of July at Las Aguas de Moises, near the highway between Cariaco and Casanay. The Campoma guppies were observed in a 
small stream of clear water. The river was about 150 $\mathrm{cm}$ deep with the bottom clearly visible, about 180 to $300 \mathrm{~cm}$ wide and no submerged vegetation was observed, the observation area was a stretch of about 40 meter. There were trees and some dense vegetation at several positions at the bank. The Campoma guppy was syntopic with the following species: Catoprion spec., Crenicichla spec., Cichlasoma spec., Rivulus spec., Ampullaria spec., and some unidentified crustaceans. The observed subpopulations, i.e., groups of about twenty adults of both sexes and about 20 subadult and juvenile fishes, occupied positions near the river banks. At different locations of this stream we observed other groups with approximately 60 adults, with about 50 subadults and juvenile fishes. The females were continuously grazing the loamy ground, swimming in groups of 6 to 10 fishes. In this stable environment, subgroups are formed consisting only of females. Stable all-female subgroups stay a relatively long time, about 20 to 30 minutes, at a certain locality within the territory, circa 100 square $\mathrm{cm}$, where they seem to be constantly foraging. Strange females rarely enter this sub-community. Intra-sexual aggression, in which the largest females chase smaller females away, was also observed. When two females are equally big, they show a particular posture. These female opposed each other in a T-shaped position for half a second, spreading their fins. After this showing off they feed again. Only at one observation we saw two opponent females actually fight, one female was picking at the caudal peduncle of the other female. After about ten seconds they started feeding again. This behaviour had no apparent effect on the group structure. Two explanations for this behaviour are possible. Firstly, the females have some territorial behaviour related to foraging. Secondly, we suspect female-to-female competition related to sexual selection, i.e., male sexual selection not observed in $P$. reticulata. This latter conclusion is supported by further observations (see below).

During the observation period, males were continuously found in the proximity of the females. With every all-female subgroup, we observed how two or three males remained proximate, i.e., the males seemed less promiscuous compared to $P$. reticulata. In one case, such group was accompanied by a single male. In groups with more fishes, i.e., more than 40 adults, the males court more intensive. In relatively small groups, e.g., one to three males and one to seven fe- males, the males show less intensive courtship behaviour compared to bigger groups. Males in smaller groups apparently need not show their fitness so often, because the females probably recognise individual males. When a male not already belonging to the subgroup started to show courtship behaviour to one of the females, the male already present showed the strange male his sigmoid display, after which the intruder stopped his courtship attempt. Males that initiate courtship approach the female from behind, preferably while she is busy searching food. As noted above, females are mostly stationary during foraging.

Observations indicated that the introduction phase in the Campoma guppy is relatively short compared to common guppies, whereas the last phase of their courtship behaviour, i.e., high courtship, is longer and more intensive. Correlated to the behavioural characteristics of $P$. reticulata (Table III), we recorded the following.

1a. A male attempts to position himself under the female, while his colour pattern darkens if he is successful.

2a. The male will attempt to become visible in the face-to-face position.

2b. He initiates the sigmoid-display. During the sigmoid-display the male turns both sides to the female, like the common guppy.

2c. Finally the male circles around the female and attempts to copulate with his forwardly turned gonopodium.

The significant differences between the courtship behaviour of the common guppy and the Campoma guppy, documented from about 35 observational moments, is summarised as follows.

- The Campoma guppy males court more from below during the first phase of the courtship behaviour. The males from the common guppy swim more from behind or from the side of the females.

- Because the female of the Campoma guppy did not flee, we did not observe any chasing from the males. The females float slowly in front of the males and show that they are co-operative. Females of the common guppy make clear, in a relatively early stage of courtship, whether they are inclined to copulate or not.

- The characteristic display jump of the common guppy during the courtship is only rarely observed in the Campoma guppy. We, therefore, assume that the display jump is not important for the courtship behaviour of the Campoma guppy. 
- The females of the Campoma guppy swim away from the courting males when they attempt to copulate, i.e., they avoid courting males relatively late. The females from $P$. reticulata often flee at the beginning of the courtship. We never saw any aggression from the Campoma guppy females towards courting males. Under natural conditions, as well as in an aquarium, females of the common guppy attack obtrusive males. In general, the females of the Campoma guppy seem longer co-operative and receptive, rejecting males in a much later stage than do females of the common guppy.

- The courtship of the Campoma guppy male is relatively docile. Moreover, males attempt to court the same female longer and, after failure, often start to court the same female again.

- Although the competition is strong in big populations, we never saw a Campoma male attempting to court a female that is already courted by another male. The males in a big group show impressing behaviour only on occasion. We assume that inter-male aggression is not relevant for courtship in a big group.

- We observed sneak-copulation, i.e., copulation attempts without elaborate courtship, in the Campoma guppy too, but it is another kind of sneakcopulation, i.e., we never observed sneaky copulations without previous courtship. Common guppies will try to copulate without any prior courtship (cf. Houde, 1997).

Despite intensive observations no particular predator was found that directly attacked guppies. For example, in all locations, juvenile and subadult Campoma guppies were close to the Rivulus-like fish near the riverbanks. We did not find any Rivulus attacking any young guppies. At Las Aguas des Moises, adult guppies were found near a pair of Crenicichla with juveniles. No Crenicichla did pursue guppies, and in one occasion a subadult Crenicichla was seen to actually 'pass through' a shoal of guppies. No reason for this 'non-aggression pact' is apparent.

\section{Remarks on population differentiation in Trini- dadian guppies}

In a paper on guppy population differentiation, Magurran (1998) posed an enigmatic dilemma: "Guppy populations evolve rapidly ... The rates of evolution involved can be up to seven orders of magnitude greater than those seen in the fossil record ... female choice appear to reinforce the divergence ... [however] perplexingly ... there is no reproductive isolation ... between populations ..." A substantial counteraction against speciation seemed to be 'sneaky mating', i.e., the mechanism enabling males to copulate without the consent of the females. Also different foraging niches for males and females is supposed to inhibit the development of feeding polymorphism, and therefore inhibit sympatric speciation (Magurran, 1998). This enigma was generated by the occurrence of genetic differentiation between guppies from the Quare-Orupuche drainage versus guppies from the Paría drainage on Trinidad (Fajen and Breden, 1992; Taylor and Breden, 2000). The guppies from the Trinidadian Paría drainage are closely related to Venezuelan and Guyanan mainland populations, whereas the Quare-Orupuche guppies form a separate monophyletic clade. Our discovery of the Campoma guppy gives the derivation of the Quare-Orupuche guppies a possibly different perspective.

Trinidadian guppies interbreed readily in laboratory circumstances with Campoma guppies (Houde, 1997; pers. obs.), although this seemed not to be the case in the late 1970's (see below in our discussion on the Endler's Live-bearer; Alexander and Breden, 2004). The geological environment, protecting the Campoma region from invasion of the Orinoco guppy, allows only a limited influx of foreign guppies into the region. Here, separation of the two guppy populations is secured by sexual selection, and subsequent character displacement reinforcing divergence (cf. Houde, 1997; Magurran, 1998). However, it is not unlikely that, while there might have been an initial separation on species level present on Trinidad, the geology of Trinidad did not allow for an enduring separation of these two species. While the dispersal from river to river in the Cumaná-Cariaco coastal strip limits the possibilities for guppies to enter the Campoma region, the Orinoco river probably provides a continuous 'bombardment' of heterospecific genetic material in the original Trinidadian guppies. These latter guppies might have been the same species as the Campoma guppies, or a closely related population. Ongoing introgression of Orinoco guppy genes has despeciated the original Trinidadian guppy, causing the genetic divergence observed today (Fajen and 
Breden, 1992; Taylor and Breden, 2000). Therefore, the initial situation postulated by Magurran (1998) must be redefined. While she initially situated a single guppy species on Trinidad, diverging to the limit of speciation but, 'perplexingly', not going beyond that specific boundary, we postulate another scenario. The present day situation results from the introgression of genetic material of one species, viz., the Orinoco or common guppy, into a heterospecific population of 'original' Trinidadian guppies, actually converging genetic differences, i.e., despeciating the latter species. This despeciation in action was also already recorded, though not recognised as such. Magurran et. al. (1992) sampled molecular data from a guppy population that was supposed to be re-allocated by Haskins in 1957 from the Caroni drainage, i.e., part of the Paría drainage guppy populations, viz., Orinoco guppies, and removed them to the Orupuche drainage. There these Paría guppies replaced the residing guppies almost totally, a striking example of obvious higher fitness of the common guppy.

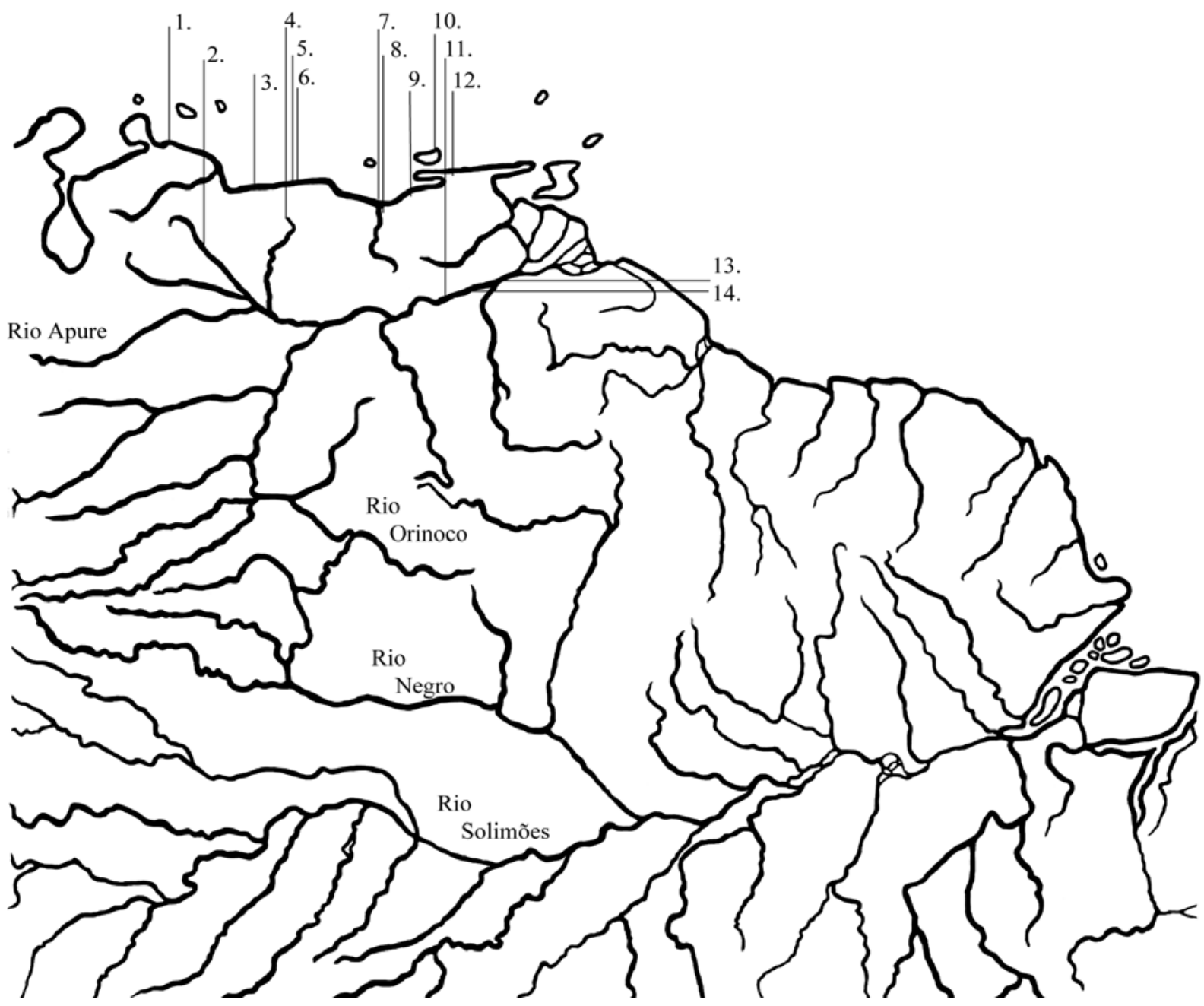

Fig. 9. Distribution area of the subgenus Acanthophacelus. The occurrence of Common guppies in the Río Santo Domingo, near Merida and the Río Apure, Llanos, Venezuela (both western rivers of the Río Orinoco drainage) is confirmed by Kempkes (pers. obs.). Guppies claimed from the Rio Solimões are kept alive by Poeser. Occurrence of guppies upstream of the Río Orinoco and in the Rio Negro awaits confirmation. Numbered locations indicate examined museum material (bold numbers are figured): 1. ZMA 120.725; 2. UMMZ 158750; 3. UMMZ 158736; 4. UMMZ 158753; 5. UMMZ 158709; 6. UMMZ 158729; 7. UMMZ 158704; 8. UMMZ 158705; 9. UMMZ 158715; 10. UMMZ 158706; 11. UMMZ 158716; 12. UMMZ 158715; 13. UMMZ 158711; 14. UMMZ 158720. 
Magurran (1998) dated the renewed contact of the common guppy with the original Trinidadian guppy very recent, i.e., 1,000-10,000 years ago, i.e., during the period that Venezuela was linked to Trinidad by the Cordilleras de la Costa. Molecular data (Fajen and Breden, 1992) date the break up between these two guppy populations long before this, i.e., 600,000 years ago. We, therefore, postulate that the Cordilleras were formed 600,000 years ago, blocking gene flow between the several populations of guppies. The Cordilleras also blocked the Río Orinoco from its northerly flow, redirecting its course just south of a rocky strip that is the present day northern range on Trinidad. Since about 10,000 years ago, this mountainous strip was severed from the Paría Peninsula and collected substantial strips of sand deposited by the Orinoco river, forming present-day Trinidad. The common guppy established itself firmly in the southeasterly drainages, whereas the Oru- puche guppies retained some of their original genetic content. On the Paría Peninsula, the Campoma guppies have kept their specific identity since, whereas the Trinidadian guppies have lost this identity by the constant intrusion of Orinoco influences.

This hypothesis is testable. Obviously, when the molecular data of the Campoma guppy are compared with those of the two clades found on Trinidad (Taylor and Breden, 2000), we predict a closer relationship of the Campoma guppy with the guppies from the Orupuche drainage than to those from the Paría drainage.

\section{Remarks on the 'Endler's Live-bearer'}

The populations of Campoma-like guppies collected in a coastal area of Venezuela, in Cumaná, Laguna de los Patos (Endler, pers. comm.), might very well

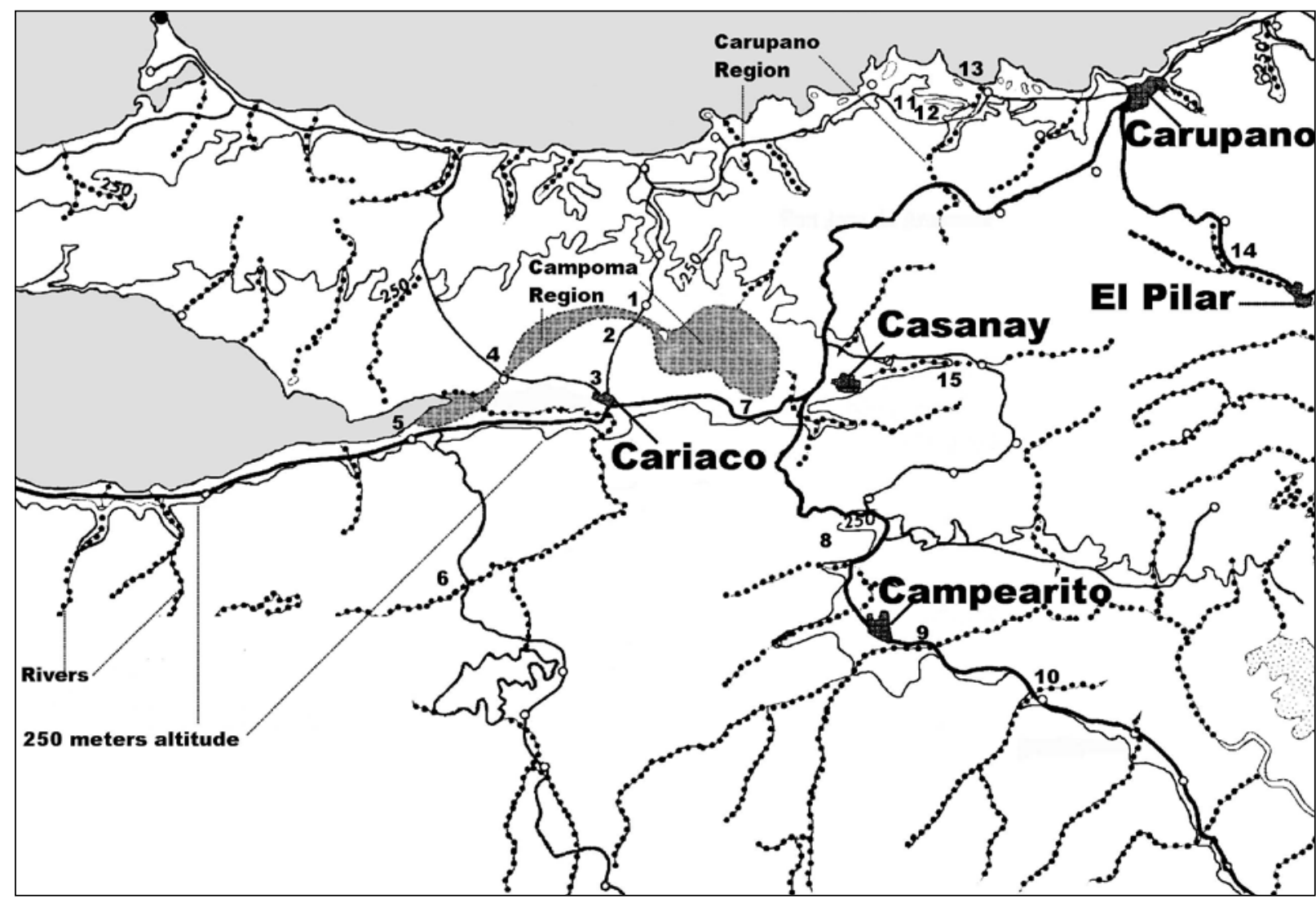

Fig. 10. Map of the collection sites in and around the Paría Peninsula, Venezuela. Indicated are river systems, the Campoma- and Carúpano regions, and the $250 \mathrm{~m}$ altitudes. Localities 1-4, and 7 rendered Campoma guppies, Campoma variety. Localities 11-13, and 15 rendered Campoma guppies, Carúpano variety. All other, non-Paría localities, rendered Common guppies. 
be an established local population of $P$. wingei. How guppies were distributed there is unknown; they might be remains of an earlier, wider range of the Campoma guppy, but most likely they are released aquarium specimens originating from the CariacoCarúpano region.

The Endler's live-bearer is renamed as "Cumaná guppy” by Alexander and Breden (2004). This vernacular name is misleading because not all guppies from Cumaná they collected are named as such (Alexander and Breden, 2004: 3), only those from the west part of Cumaná. The paper of Alexander and Breden (2004) adds a lot of quantitative data to our findings, confirming $P$. wingei as a valid species. They quantified sexual isolation, adding sexual selection and different male display traits to our findings of behavioural differences (Alexander and Breden, 2004: 5). They also added clear morphological differences to the description of the two guppy species (Alexander and Breden, 2004: 4, fig. 6 ), as well as a full examination of the differences in colour patterns also mentioned in the present paper (Alexander and Breden, 2004: 3, 7, figs. 3-5). Finally, they recorded only common guppies in a radius of $100 \mathrm{~km}$ outside Cumaná, confirming the presence of exclusively $P$. reticulata populations between Cumaná and the Paría Peninsula. Alexander and Breden (2004) recorded a total lack of reproductive (postzygotic) isolation between their Cumaná guppies and other guppy populations, although they did mention the initial incompatibility of Endler's guppies with $P$. reticulata. This makes sense in the light of our hypothesis of human introduction: the initial isolation, existing in the late 1970 's, is now broken down, possibly by introduction of $P$. reticulata genes into the Cumaná population of $P$. wingei by sneak copulations.

\section{Acknowledgements}

Our warm thanks extend to Mr. Luis Palacio, who drove us to places we would not find without him. We also thank Mr. Latsy Nyari for loaning us his notes on the Endler's Live-bearer. Mr. Jan van Arkel provided us with the photographs of the specimens shown in Figs. 1-6, and Fig. 8, for which we are grateful. Mr. Pieter J. Michels kindly read an earlier version of the manuscript and offered valuable suggestions.

\section{References}

Albers PCH. 2000. Evidence for evolution of guppies in a seminatural environment. Neth. J. Zool. 50 (4): 425-433.

Alexander HJ, Breden F. 2004. Sexual isolation and extreme morphological divergence in the Cumaná guppy: a possible case of incipient speciation. J. Evol. Biol. 17 (6): 1238-1254.

Baerends GP, Brouwer R, Waterbolk HT. 1955. Ethological studies on Lebistes reticulatus (Peters). I. An analysis of the male courtship pattern. Behaviour 8: 249-334.

Breden F, Ptacek MB, Rashed M, Taphorn D, Figueiredos CA. 1999. Molecular phylogeny of the life-bearing fish genus Poecilia (Cyprinodontiformes: Poeciliidae). Mol. Phyl. Ev. 2 (12): 95-104.

Brown WL, Wilson EO. 1956. Character Displacement. Syst. Zool. 5 (2): 49-64

Boulenger EG. 1912. Notes on the breeding habits of the "Millions" fish (Girardinus poecilioides). Proc. Zool. Soc. London 11: 906-908.

Clark E, Aronson LR. 1951. Sexual behavior in the guppy, Lebistes reticulatus (Peters). Zoologica 36: 49-66.

Costa WJEM. 1991. Description d'une nouvelle espèce du genre Pamphorichthys (Cyprinodontiformes: Poeciliidae) du basin de l'Araguaia, Brésil. Rev. fr. Aquariol. Herpétol. 2 (18): 39-42.

Costa WJEM, Sarraf A. 1997. Poecilia (Lebistes) minima, a new species of neotropical poeciliid fish from the Brazilian Amazon. Ichthyol. Explor. Freshwaters 8 (2): 185-191.

Eigenmann CH. 1907. The poeciliid fishes of Río Grande do Sul and the La Plata Basin. Proc. U. S. Natl. Mus. 7: 425-433.

Fajen A, Breden F. 1992. Mitochondria DNA sequence variation among natural populations of the Trinidad guppy, Poecilia reticulata. Evolution 46 (5): 1457-1465.

Filippi F. de. 1861. Note Zoologiche IV. Lebistes, nuovo genere di perce della famiglia dei Ciprinodonti. Tav. IV, Fig. 6. Arch. Zool. l'Anatomia e la Fisiol. (Genova), 1: 69-70, pl. IV.

Gabor CR, Ryan MJ. 2001. Geographic variation in reproductive character displacement in mate choice by male sailfin mollies. Proc. Roy. Soc. London (series B) 268:1063-1071.

Günther A. 1866. Catalogue of fishes in the British Museum. Catalogue of the Physostomi, containing the families Salmonidae, Percopsidae, Galaxidae, Mormyridae, Gymnarchidae, Esocidae, Umbridae, Scombresocidae, Cyprinodontidae, in the collection of the British Museum. Cat. Fishes 6: i-xv, 1-368.

Houde AE. 1997. Sex, colour, and mate choice in guppies. Princeton University Press, monogr. behav. ecol. ISBN 0-69102790-0: 1-210.

Liley NR. 1966. Ethological isolating mechanisms in four sympatric species of poeciliid fishes. Behaviour (Suppl.) 13: 1-197.

Magurran AE, Seghers BH, Carvalho GR, Shaw PW. 1992. Behavioural consequences of an artificial introduction of guppies (Poecilia reticulata) in N. Trinidad: evidence for the evolution of antipredator behaviour in the wild. Proc. $R$. S. Lond. Ser. B-Biol. Sci. 248:117-122.

Magurran AE. 1998. Population differentiation without speciation. Phil. Trans. R. Soc. London B 353: 275-286.

Meyer MK. 1993. Re-instatement of Micropoecilia Hubbs, 1926, with a redescription of $M$. bifurca (Eigenmann, 1909) from 
Northeast South America (Teleostei, Cyprinodontiformes: Poeciliidae). Zool. Abh. Staatl. Mus. Tierk. 47 (10): 121-130.

Murray JD. 1988. How the leopard gets its spots. Sci. Amer. (3): 80-87

Nicoletto PF. 1993. Female sexual response to condition-dependent ornaments in the guppy, Poecilia reticulata. Anim. Behav. 49: 377-387.

Paepke HJ. 1986. Neues zur Entdeckungsgeschichte von Poecilia reticulata. Aquarien Terrarien 6: 192-194.

Peters WCH. 1859. Hr. W. [C.H.] Peters legte eine neue von Hrn. Jagor im atlantischen Meere gefangene Art der Gattung Leptocephalus vor und fügte Mittheilungen über einige andere neue Fische des zoologischen Museums hinzu. Monatsb. Akad. Wiss. Berlin [Gesammtsitzung vom 9. Juni 1859] : 411-412.

Poeser FN. 1995. Nonrandom variation in Poecilia marcellinoi n. sp. and P. salvatoris Regan, 1907 in El Salvador (Pisces, Poeciliidae). Bijdr. Dierk. 64 (4): 239-252.

Poeser FN. 1998. The role of character displacement in the speciation of Central American members of the genus Poecilia (Poeciliidae). Ital. J. Zool. 65 Suppl.: 145-147.

Poeser FN. 2003. From the Amazon river to the Amazon molly and back again. Ph.D. thesis (University of Amsterdam), ISBN 90-76894-32-9: i-xxiv, 1-180.

Poeser FN, Isbrücker IJH. 2002. Zum wissenschaftlichen Name des Guppy. DATZ 4: 47-49.

Ptacek MB, Breden F. 1998. Phylogenetic relationships among mollies (Poeciliidae: Poecilia: Mollienesia group) based on mitochondrial DNA sequences. J. Fish Biol. 53 (Suppl. A): 64-81.

Regan CT. 1913. A revision of the cyprinodont fishes of the subfamily Poeciliinae. Proc. Zool. Soc. Lond. 11: 977-1018.

Reznick DN. 1982. The impact of predation on the life history evolution in Trinidadian guppies: genetic basis of observed life history patterns. Evolution 36 (6): 1236-1250.

Reznick DN. 1983. The structure of guppy life history: the tradeoff between growth and reproduction. Ecology 64 (4): 862 873.

Reznick DN, Bryga HA. 1996. Life-history evolution in guppies V. Genetic basis of parallelism in life histories. Am. Nat. 147: 339-359.
Reznick DN, Butler M, Rodd F, Ross P. 1996. Life-History evolution in guppies VI. Differential mortality as a mechanism for natural selection. Evolution 4: 1651-1660.

Reznick DN, Rodd F, Cardenas M. 1996. Life-history evolution in guppies IV: Parallelism in life-history phenotypes. Am. Nat. 147: 319-338.

Rivas LR. 1982. Character displacement and coexistence in two poeciliid fishes of the genus Poecilia (Mollienesia) from Hispaniola. Northeastern Gulf Sci. 5 (2): 1-24.

Robinson BW, Wilson DS. 1995. Experimentally induced morphological diversity in Trinidadian guppies (Poecilia reticulata). Copeia 1995: 294-305.

Rodriguez CM. 1997. Phylogenetic analysis of the tribe Poeciliini (Cyprinodontiformes: Poeciliidae). Copeia 4 (1997): 663-679.

Rosen DE, Bailey RM. 1963. The poeciliid fishes (Cyprinodontiformes), their structure, zoogeography, and systematics. Bull. Am. Mus. Nat. Hist. 126: 1-176.

Schmidt J. 1920. Racial investigations. IV. The genetic behaviour of a secondary sexual character. Comptes-rendus Lab. Carlsberg 14 (8): 1-12, Pl. I-V.

Szybalskia W. 2001. My Road to Øjvind Winge, the Father of Yeast Genetics. Genetics 158:1-6.

Taylor JS, Breden F. 2000. Slipped-strand mispairing at noncontiguous repeats in Poecilia reticulata: A model for minisatellite birth. Genetics 155: 1313-1320.

Trewavas E. 1948. Cyprinodont fishes of San Domingo, Island of Haiti. Proc. Zool. Soc. Lond. 118 (2): 408-415

Turing A. 1952. The chemical basis of morphogenesis. Phil. Trans. Roy. Soc. Lond. 237: 5-72.

Westerhof IJ. 1960. Sexualiteitsverschijnselen en genenanalyse bij Lebistes reticulatus Peters. Ph.D. thesis (A.J. Osinga, Bolsward Publ.): 1-103, P1. I-VI.

Winge Ø. 1922. One-sided masculine and sex-linked inheritance in Lebistes reticulatus. J. Gen. (12): 145-162.

Winge Ø. 1927. The location of eighteen genes in Lebistes reticulatus. J. Gen. (3): 1-37.

Received: 22 December 2004

Accepted: 8 September 2005 
